\title{
Evaluation of Al-Thagher Wastewater Treatment Plant
}

\author{
Abdulhussain A. Abbas ${ }^{1 *}$, Yasameen Tahseen Yousif ${ }^{1}$, Heider Hamid Almutter $^{1}$ \\ ${ }^{1}$ Department of Civil Engineering, Faculty of Engineering, University of Basrah, P.O.Box 49, Basrah, Iraq \\ *Corresponding author, e-mail: abdulhussain.abbas@uobasrah.edu.iq
}

Received: 06 May 2021, Accepted: 21 September 2021, Published online: 29 September 2021

\begin{abstract}
This study aims to evaluate the performance of the sewage treatment plant in Al-Thagher city, in the north of Basrah governorate, the southern part of Iraq. The plant's performance was estimated based on an analysis of influent and effluent wastewater quality data that represented the monthly averages from Feb. 2017 to Dec. 2018. The results show that the values of temperature (T), $\mathrm{pH}$, ammonia $\left(\mathrm{NH}_{3}-\mathrm{N}\right)$, chemical oxygen demand (COD) and biological oxygen demand (BOD) in all collected samples from the effluent of the plant met the Iraqi water quality standard (IWQS), whereas the values of electrical conductivity (EC), total dissolved solids (TDS), total suspended solids (TSS), sulfate $\left(\mathrm{SO}_{4}^{-2}\right)$, chloride $\left(\mathrm{Cl}^{-1}\right)$ and phosphate $\left(\mathrm{PO}_{4}-\mathrm{P}\right)$ met the Iraqi water quality standard (IWQS) in some months and did not meet the standard in other months. The average removal efficiencies were in the following order: $\operatorname{COD}(77.12 \%)>$ $\mathrm{BOD}(77.03 \%)>\mathrm{TSS}(62.26 \%)>\mathrm{NH}_{3}-\mathrm{N}(59.99 \%)>\mathrm{PO}_{4}-\mathrm{P}(12.42 \%)>\mathrm{Cl}^{-1}(1.97 \%)$. The removal percentages for the remaining parameters had negative values. The Canadian Council of Ministers of the Environment water quality index (CCME WQI) value of the treated water was 51.80 and classified as "marginal." The coefficients of determination between each parameter in influent or effluent were calculated. Finally, linear regression equations between these parameters were formulated so that the value of one parameter could be used to predict the value of a different parameter.
\end{abstract}

Keywords

sewage treatment plants, performance evaluation, wastewater characteristics, BOD, COD, TSS, CCME WQI

\section{Introduction}

Wastewater is created from residential, institutional, commercial and industrial activities [1]. Wastewaters are commonly polluted with physical, chemical, and biological compounds, all of which have a significant negative effect on the environment, with the potential to destroy many habitats and irreversibly harm ecosystems [2]. The release of raw wastewater into watercourses has negative impacts on the environment and human health. Hence, wastewater should be properly treated before it is discharged into surface water or land to protect the health of inhabitants of both rural and urban communities. Therefore, wastewater is collected and transported via a network of pipes to a wastewater treatment plant (WWTP) [3].

Typically, wastewater treatment involves three stages, called primary, secondary and tertiary treatment. The degree of reduction of biochemical oxygen demand (BOD) and total suspended solids (TSS), which constitute organic waste, is the general yardstick for measuring the efficiency of WWTPs. Improper operation of WWTPs may bring serious environmental problems, as its effluent is discharged to a water body [4]. The efficiency of wastewater treatment is a basic indicator of WWTP function [5]. WWTP performance must be evaluated to assess effluent efficiency, satisfy treatment criteria, and determine whether the treatment plants can accommodate higher hydraulic organic loadings [6]. Established facilities may be modified to accommodate higher hydraulic and organic loads, but meeting higher treatment standards typically necessitates substantial expansion or alteration of existing facilities [7]. Frequent field and laboratory measurements are important tools for proper treatment process control and management [8]. Much research worldwide has investigated and analyzed WWTP effectiveness, including studies in the United States [9-11] and Iraq [12-14].

The water quality index (WQI) provides a single dimensionless value using mathematical equations that indicate the overall water quality under specified conditions of time and location depending on various water quality parameters. A WQI is a tool used by scientists, decision-makers, stakeholders, and governmental authorities 
and agencies to facilitate smart management of water quality issues [15-17]. Since 1967, numerous scholars and agencies have presented many water quality indices for water quality assessment [17]. The most widely used WQIs were developed by the National Sanitation Foundation (NSF WQI) and the Canadian Council of Ministers of the Environment (CCME WQI) [18]. In 2021, Uddin et al. reviewed WQI applications found in literature published from 1960 to 2019, and they concluded that the CCME and NSF water quality indices have been used in more than $50 \%$ of the reviewed studies [17].

The advantages of the CCME WQI over other water quality indices are its ease of application, flexibility in choosing the lowest water quality parameters (only four) to be included in the model, flexibility in the selection criteria, relative strictness compared to other indices, suitability for water quality evaluation in specific places, compliance with various legal standards for various water usage, and tolerance for missing data [17-19]. Therefore, the CCME WQI has been widely applied to many surface and groundwater bodies in Iraq [20, 21] and other countries [22-27]. Recently, the CCME WQI has been used to evaluate the quality of treated water [28-34]. Thus, WQI is also a helpful and useful tool for researchers and decision-makers to monitor and assess the treated wastewater quality for any purpose [33, 34].

This research aims to examine the performance of the Al-Thagher WWTP in Basrah Governorate, in southern Iraq. This evaluation could be used to facilitate effluent quality assessment or optimal process control of the plant. Influent characterization was conducted to determine wastewater strength. All studied parameters (TSS, COD, BOD, temperature (T), $\mathrm{pH}$, electrical conductivity (EC), total dissolved solids (TDS), sulfate $\left(\mathrm{SO}_{4}^{-2}\right)$, chloride $\left(\mathrm{Cl}^{-1}\right)$, ammonia $\left(\mathrm{NH}_{3}-\mathrm{N}\right)$, and phosphate $\left.\left(\mathrm{PO}_{4}-\mathrm{P}\right)\right)$ of the effluent were compared with the Iraqi water quality standard (IWQS) to determine whether they meet this standard. Then, the CCME WQI was calculated for the effluent. This study also investigated the strength of the correlation between pairs of parameters to establish a linear regression between them.

\section{Materials and methods}

\subsection{Al-Thagher WWTP}

The Al-Thagher WWTP is located at Al-Thagher city in the northern part of Basrah governorate on the Tigris River (31 $\left.{ }^{\circ} 41^{\prime \prime} \mathrm{N}, 47^{\circ} 26^{\prime} 43^{\prime \prime} \mathrm{E}\right)$, as shown in Fig. 1. The plant treats wastewater from the city of Al-Thagher. The Al-Thagher

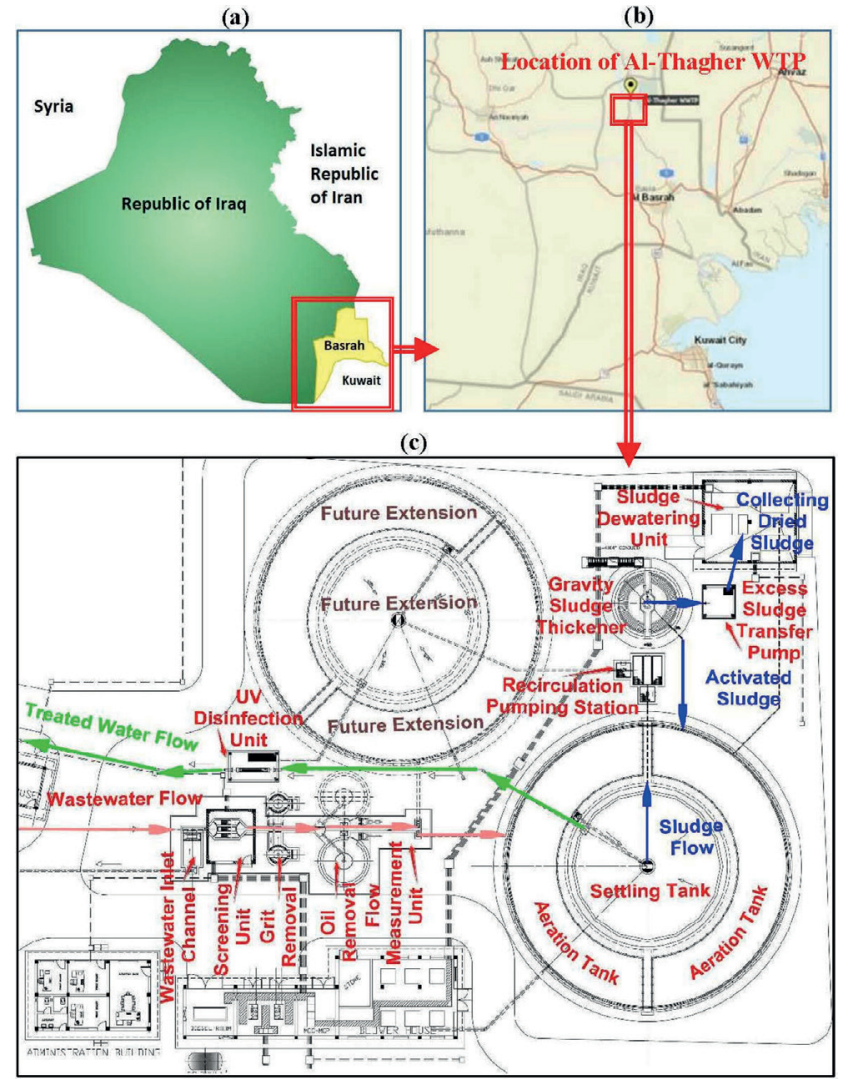

Fig. 1 Study Area: (a) Iraqi Map, (b) Basrah Map, (c) Al-Thagher WWTP layout

WWTP was built in 2016 and designed to work until 2036. The total area of the treatment plant is $3600 \mathrm{~m}^{2}$, and it serves more than 6000 people in one of the biggest governorates of the country. The output capacity of the treatment plant is $2800 \mathrm{~m}^{3} /$ day and may reach $3100 \mathrm{~m}^{3} /$ day at peak [35].

The plant uses the extended aeration-activated sludge (EAAS) process. Extended aeration plants are designed to require the plant operator to manage minimal routine housekeeping and operational tasks. The designed process units include one sand trap to filter rain wastewater, an inlet wastewater channel, a screening room, a grit chamber, a flow meter channel, a wastewater distribution box, an aeration unit based on extension aeration, a settling tank with sludge scraper, a UV disinfection channel, a gravity sludge thickener, a thickened sludge pump station, a polyelectrolyte dosing station and a sludge mixing tank with polyelectrolyte and sludge belt filter press, as shown in Fig. 2. A circular design is used to optimize the space; the main clarifier is located in a circular basin. The aeration tank surrounds the clarifier on the outside and is concentric to the clarifier. A scraper mechanism is installed inside the main clarifier to collect and remove sludge from the bottom. The wastewater is first screened 


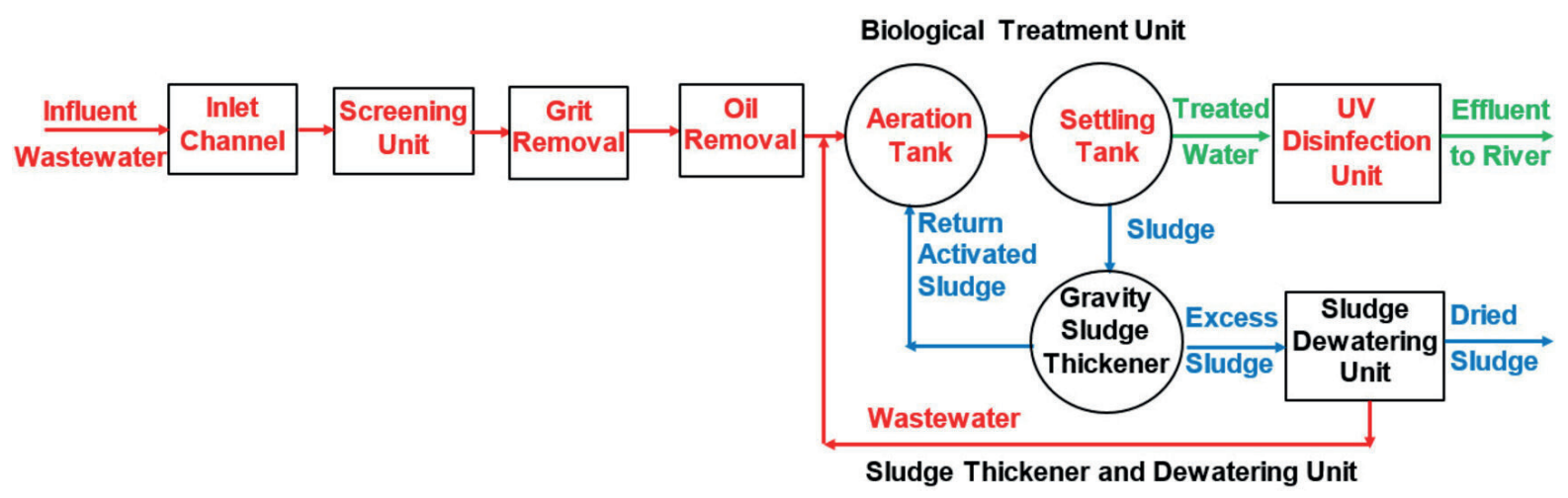

Fig. 2 Treatment processes flow chart of the Al-Thagher WWTP

and then flows into the aeration tank. The main clarifier is used to remove the activated sludge; some amount returns to the aeration tank to seed the incoming wastewater while the remainder is transferred to the sludge digester (Fig. 1(c) and Fig. 2). Sludge is thickened and dewatered on-site. Treated effluent from the plant discharges to a nearby stream [35]. The plant is controlled under the main operation conditions listed in Table 1.

\subsection{Data collection and analysis}

The data used in this paper were provided from the Al-Thagher WWTP for the period from February 2017 to December 2018. The data represented the average monthly values of the main influent and effluent parameters. The main parameters are T, $\mathrm{pH}, \mathrm{EC}$, TDS, TSS, $\mathrm{SO}^{-2}, \mathrm{Cl}^{-1}$, $\mathrm{NH}_{3}-\mathrm{N}, \mathrm{PO}_{4}-\mathrm{P}, \mathrm{COD}$ and BOD. Samples were obtained and analyzed at the Al-Basrah WWTP's laboratory. Influent samples were obtained after the grit chamber unit, and effluent samples were taken after the disinfection stage. Standard methods were used to determine the concentration of the parameters [36]. Simple descriptive statistics were used to tabulate and analyze the data.

Table 1 Operating conditions of the Al-Thagher WWTP

\begin{tabular}{|c|c|c|c|}
\hline \multicolumn{2}{|c|}{ Operation Parameter } & Value & Unit \\
\hline SRT & Sludge Retention Time & $20-40$ & day \\
\hline MLSS & $\begin{array}{l}\text { Mixed Liquor Suspended } \\
\text { Solids }\end{array}$ & $2000-5000$ & $\mathrm{mg} / \mathrm{L}$ \\
\hline HRT & Hydraulic Retention Time & $20-30$ & hours \\
\hline $\mathrm{Q}_{\mathrm{r}} / \mathrm{Q}_{0}$ & $\begin{array}{c}\text { Return Activated Sludge } \\
\text { (Qr) as \% of Incoming } \\
\text { Flow (Q0) }\end{array}$ & $50-150$ & $\%$ \\
\hline $\mathrm{F} / \mathrm{M}$ & Food / Microorganisms & $0.04-0.1$ & $\begin{array}{c}\mathrm{kg} \text { BOD/ } \\
\mathrm{kg} \text { MLVSS/day }\end{array}$ \\
\hline DO & Dissolved Oxygen & $2-4$ & $\mathrm{mg} / \mathrm{L}$ \\
\hline
\end{tabular}

\section{Results and discussion}

\subsection{Influent characteristics}

Raw wastewater must be characterized to select appropriate treatment technology, design efficient treatment facilities and evaluate the efficiency of different processes. Table 2 shows the concentrations and statistics of the studied parameters in the influent wastewater for 23 months from February 2017 to December 2018. Averages, standard deviations and maximum and minimum values were calculated for the main parameters from the data. Table 3 shows the strong, medium and weak strengths of the compositions of typical municipal wastewater according to Metcalf and Eddy et al. [1].

According to the typical wastewater classification in Table 3, the measured $\mathrm{pH}$ values (6.9-7.4) in raw wastewater were within the medium range of typical wastewater value (7-9). The $\mathrm{pH}$ values in most months were equal or slightly higher than 7 except for three months (Feb. 2017, Oct. 2018, and Dec. 2018), when the value was less than 7 by 0.1 .

The measured electrical conductivity (EC) values $(1362-4396 \mu \mathrm{s} / \mathrm{cm})$ in raw wastewater varied between strong $(>1500 \mu \mathrm{s} / \mathrm{cm})$ and medium $(1000-1500 \mu \mathrm{s} / \mathrm{cm})$. The EC values in most months were higher than $1500 \mu \mathrm{s} / \mathrm{cm}$ except for two months (May 2017 and Jun. 2017).

The measured total dissolved solids (TDS) concentrations $(756-3070 \mathrm{mg} / \mathrm{L})$ in raw wastewater varied between strong (> $1000 \mathrm{mg} / \mathrm{L})$ and medium (500-1000 mg/L). The TDS concentrations in most months were higher than $1000 \mathrm{mg} / \mathrm{L}$ except for three months (May 2017, Jun. 2017, and Sep. 2018).

The measured concentrations of $\mathrm{SO}_{4}^{-2}(199-1085 \mathrm{mg} / \mathrm{L})$ in raw wastewater were within the strong range $(>100 \mathrm{mg} / \mathrm{L})$ of typical wastewater concentrations. The $\mathrm{SO}_{4}^{-2}$ concentrations were higher than $100 \mathrm{mg} / \mathrm{L}$ in all months. 
Table 2 Influent wastewater characteristics at the Al-Thagher WWTP

\begin{tabular}{|c|c|c|c|c|c|c|c|c|c|c|c|c|}
\hline Month & $\mathrm{T}$ & $\mathrm{pH}$ & $\mathrm{EC}$ & TDS & TSS & $\mathrm{SO}_{4}^{-2}$ & $\mathrm{Cl}-1$ & $\mathrm{NH}_{3}-\mathrm{N}$ & $\mathrm{PO}_{4}-\mathrm{P}$ & COD & BOD & $\mathrm{BOD} / \mathrm{COD}$ \\
\hline Feb-17 & $16.8 \pm 3.2$ & $6.9 \pm 0.07$ & $3166 \pm 449$ & $1626 \pm 402$ & $134 \pm 73$ & $386 \pm 110$ & $523 \pm 75$ & $14.9 \pm 5.5$ & $1.4 \pm 0.8$ & $85 \pm 22$ & $39 \pm 19$ & 0.46 \\
\hline Mar-17 & $21.9 \pm 3.0$ & $7.0 \pm 0.04$ & $4396 \pm 558$ & $2096 \pm 346$ & $290 \pm 89$ & $441 \pm 87$ & $667 \pm 53$ & $1.7 \pm 1.0$ & $0.4 \pm 0.3$ & $187 \pm 24$ & $76 \pm 17$ & 0.41 \\
\hline Apr-17 & $26.0 \pm 3.7$ & $7.2 \pm 0.03$ & $2879 \pm 399$ & $1426 \pm 457$ & $189 \pm 62$ & $320 \pm 107$ & $475 \pm 89$ & $7.4 \pm 4.5$ & $0.3 \pm 0.2$ & $218 \pm 38$ & $86 \pm 22$ & 0.40 \\
\hline May-17 & $29.7 \pm 3.9$ & $7.3 \pm 0.05$ & $1362 \pm 376$ & $756 \pm 377$ & $65 \pm 41$ & $199 \pm 101$ & $284 \pm 71$ & $13.2 \pm 6.0$ & $0.3 \pm 0.2$ & $228 \pm 36$ & $90 \pm 21$ & 0.39 \\
\hline Jun-17 & $34.9 \pm 4.4$ & $7.2 \pm 0.05$ & $1447 \pm 700$ & $957 \pm 330$ & $32 \pm 14$ & $204 \pm 139$ & $338 \pm 58$ & $12.0 \pm 4.0$ & $2.1 \pm 1.5$ & $205 \pm 35$ & $81 \pm 29$ & 0.39 \\
\hline Jul-17 & $38.0 \pm 3.8$ & $7.1 \pm 0.02$ & $1658 \pm 721$ & $1260 \pm 304$ & $21 \pm 13$ & $217 \pm 91$ & $393 \pm 83$ & $10.8 \pm 6.0$ & $3.8 \pm 2.1$ & $175 \pm 41$ & $72 \pm 32$ & 0.41 \\
\hline Aug-17 & $35.5 \pm 4.0$ & $7.2 \pm 0.05$ & $1964 \pm 646$ & $1416 \pm 387$ & $44 \pm 19$ & $267 \pm 142$ & $341 \pm 85$ & $14.9 \pm 6.9$ & $3.3 \pm 2.1$ & $165 \pm 28$ & $75 \pm 20$ & 0.46 \\
\hline Sep-17 & $31.1 \pm 2.9$ & $7.3 \pm 0.06$ & $2373 \pm 727$ & $1566 \pm 307$ & $71 \pm 29$ & $333 \pm 139$ & $290 \pm 86$ & $21.2 \pm 6.3$ & $2.4 \pm 1.2$ & $161 \pm 35$ & $85 \pm 16$ & 0.53 \\
\hline Oct-17 & $26.0 \pm 3.3$ & $7.2 \pm 0.01$ & $3052 \pm 574$ & $1840 \pm 447$ & $81 \pm 47$ & $384 \pm 142$ & $370 \pm 58$ & $25.5 \pm 6.1$ & $1.7 \pm 1$ & $190 \pm 41$ & $115 \pm 23$ & 0.61 \\
\hline Nov-17 & $20.6 \pm 3.4$ & $7.2 \pm 0.07$ & $3831 \pm 421$ & $2150 \pm 243$ & $87 \pm 67$ & $429 \pm 83$ & $518 \pm 68$ & $29.0 \pm 5.9$ & $1.2 \pm 0.5$ & $242 \pm 42$ & $158 \pm 26$ & 0.65 \\
\hline Dec-17 & $18.1 \pm 2.8$ & $7.1 \pm 0.06$ & $4204 \pm 475$ & $2298 \pm 423$ & $88 \pm 51$ & $455 \pm 116$ & $598 \pm 70$ & $31.7 \pm 6.6$ & $0.9 \pm 0.5$ & $271 \pm 29$ & $180 \pm 27$ & 0.66 \\
\hline Jan-18 & $18.8 \pm 3.2$ & $7.1 \pm 0.07$ & $3848 \pm 453$ & $2220 \pm 427$ & $83 \pm 36$ & $465 \pm 103$ & $533 \pm 72$ & $33.5 \pm 7.5$ & $2.9 \pm 1.6$ & $242 \pm 32$ & $174 \pm 20$ & 0.72 \\
\hline Feb-18 & $20.7 \pm 5.0$ & $7.1 \pm 0.03$ & $3188 \pm 541$ & $2043 \pm 394$ & $73 \pm 50$ & $471 \pm 141$ & $412 \pm 90$ & $34.6 \pm 4.3$ & $6.5 \pm 2.2$ & $189 \pm 39$ & $158 \pm 26$ & 0.84 \\
\hline Mar-18 & $23.3 \pm 4.7$ & $7.1 \pm 0.04$ & $2832 \pm 717$ & $1852 \pm 453$ & $68 \pm 44$ & $473 \pm 133$ & $347 \pm 54$ & $35.0 \pm 5.1$ & $8.5 \pm 3$ & $160 \pm 22$ & $130 \pm 20$ & 0.81 \\
\hline Apr-18 & $26.4 \pm 3.3$ & $7.2 \pm 0.02$ & $3302 \pm 649$ & $1676 \pm 246$ & $354 \pm 87$ & $320 \pm 146$ & $656 \pm 62$ & $16.6 \pm 7.0$ & $8.4 \pm 3.7$ & $235 \pm 25$ & $45 \pm 21$ & 0.19 \\
\hline May-18 & $26.7 \pm 2.9$ & $7.2 \pm 0.06$ & $2527 \pm 563$ & $1402 \pm 237$ & $122 \pm 93$ & $375 \pm 121$ & $555 \pm 88$ & $10.6 \pm 5.2$ & $10.5 \pm 2.1$ & $176 \pm 29$ & $70 \pm 21$ & 0.40 \\
\hline Jun-18 & $31.8 \pm 3.9$ & $7.0 \pm 0.08$ & $2390 \pm 539$ & $1036 \pm 375$ & $85 \pm 41$ & $363 \pm 85$ & $494 \pm 89$ & $13.0 \pm 4.0$ & $19.8 \pm 2.2$ & $181 \pm 22$ & $100 \pm 24$ & 0.55 \\
\hline Jul-18 & $32.7 \pm 3.6$ & $7.1 \pm 0.07$ & $2537 \pm 556$ & $1558 \pm 429$ & $46 \pm 36$ & $350 \pm 123$ & $489 \pm 74$ & $12.0 \pm 5.1$ & $8.1 \pm 2.7$ & $120 \pm 23$ & $70 \pm 16$ & 0.58 \\
\hline Aug-18 & $33.8 \pm 4.1$ & $7.4 \pm 0.07$ & $2328 \pm 508$ & $1092 \pm 240$ & $50 \pm 38$ & $312 \pm 140$ & $421 \pm 99$ & $10.2 \pm 4.0$ & $9 \pm 3.8$ & $148 \pm 27$ & $90 \pm 20$ & 0.61 \\
\hline Sep-18 & $31.6 \pm 3.1$ & $7.3 \pm 0.06$ & $1847 \pm 684$ & $830 \pm 457$ & $354 \pm 81$ & $213 \pm 108$ & $428 \pm 80$ & $15.1 \pm 7.4$ & $10.5 \pm 3.4$ & $172 \pm 31$ & $80 \pm 25$ & 0.46 \\
\hline Oct-18 & $23.8 \pm 3.3$ & $6.9 \pm 0.01$ & $3520 \pm 492$ & $2520 \pm 434$ & $220 \pm 87$ & $655 \pm 89$ & $591 \pm 85$ & $14.7 \pm 7.0$ & $8.4 \pm 2.8$ & $140 \pm 27$ & $60 \pm 18$ & 0.43 \\
\hline Nov-18 & $19.7 \pm 3.0$ & $7.1 \pm 0.03$ & $3924 \pm 511$ & $3070 \pm 415$ & $422 \pm 70$ & $1085 \pm 105$ & $670 \pm 87$ & $8.5 \pm 4.1$ & $10.2 \pm 2.1$ & $315 \pm 42$ & $60 \pm 25$ & 0.19 \\
\hline Dec-18 & $15.7 \pm 3.5$ & $6.9 \pm 0.06$ & $4320 \pm 709$ & $2108 \pm 381$ & $236 \pm 49$ & $645 \pm 130$ & $753 \pm 92$ & $9.5 \pm 4.4$ & $8.4 \pm 3.4$ & $118 \pm 22$ & $60 \pm 32$ & 0.51 \\
\hline Ave. & 26.2 & 7.1 & 2908 & 1687 & 140 & 407 & 485 & 17.2 & 5.6 & 188 & 94 & 0.51 \\
\hline $\mathrm{SD}( \pm)$ & 6.6 & 0.1 & 920 & 578 & 117 & 192 & 131 & 9.6 & 4.9 & 53 & 40 & 0.17 \\
\hline $\operatorname{Max}$ & 38 & 7.4 & 4396 & 3070 & 422 & 1085 & 753 & 35 & 19.8 & 315 & 180 & 0.84 \\
\hline Min & 15.7 & 6.9 & 1362 & 756 & 21 & 199 & 284 & 1.7 & 0.3 & 85 & 39 & 0.19 \\
\hline Class & - & - & S-M & $\mathrm{S}-\mathrm{M}$ & $\mathrm{M}-\mathrm{W}$ & $\mathrm{S}$ & $\mathrm{S}$ & $\mathrm{M}-\mathrm{W}$ & $\mathrm{M}-\mathrm{W}$ & $\mathrm{M}-\mathrm{W}$ & $\mathrm{M}-\mathrm{W}$ & W \\
\hline
\end{tabular}

Note: All values (mean $\pm \mathrm{SD})$ are expressed in $\mathrm{mg} / \mathrm{L}(\mathrm{ppm})$ except $\mathrm{pH}$ (dimensionless), EC $(\mu \mathrm{s} / \mathrm{cm})$ and temperature $\left({ }^{\circ} \mathrm{C}\right)$.

Table 3 Typical composition and strength type of wastewater [1]

\begin{tabular}{lcccc}
\hline \multirow{2}{*}{ Constituents } & Unit & \multicolumn{3}{c}{ Typical Concentration } \\
& & Strong (S) & Medium (M) & Weak (W) \\
\hline $\mathrm{pH}$ & - & 6 to 9 & 7 to 9 & 8 to 9 \\
$\mathrm{COD}$ & $\mathrm{mg} / \mathrm{L}$ & 1000 & 500 & 250 \\
$\mathrm{BOD}$ & $\mathrm{mg} / \mathrm{L}$ & 300 & 200 & 100 \\
$\mathrm{NH}_{3}-\mathrm{N}$ & $\mathrm{mg} / \mathrm{L}$ & 75 & 45 & 20 \\
$\mathrm{PO}_{4}-\mathrm{P}$ & $\mathrm{mg} / \mathrm{L}$ & 15 & 10 & 5 \\
$\mathrm{SO}_{4}^{-2}$ & $\mathrm{mg} / \mathrm{L}$ & 100 & 50 & 25 \\
$\mathrm{Cl}^{-1}$ & $\mathrm{mg} / \mathrm{L}$ & 50 & 30 & 20 \\
$\mathrm{TDS}^{-2}$ & $\mathrm{mg} / \mathrm{L}$ & 1000 & 500 & 200 \\
$\mathrm{TUR}_{\mathrm{TSS}}$ & $\mathrm{NTU}$ & 1500 & 1000 & 500 \\
$\mathrm{EC}$ & $\mathrm{mg} / \mathrm{L}$ & 400 & 210 & 120 \\
\hline
\end{tabular}

The measured concentrations of $\mathrm{Cl}^{-1}(284-753 \mathrm{mg} / \mathrm{L})$ in raw wastewater were within the strong range $(>50 \mathrm{mg} / \mathrm{L})$ of typical wastewater concentrations. The $\mathrm{Cl}^{-1}$ concentrations were higher than $50 \mathrm{mg} / \mathrm{L}$ in all months.

The high concentrations of salt parameters (EC, TDS, $\mathrm{SO}_{4}{ }^{-2}$, and $\mathrm{Cl}^{-1}$ ) are due to the saltwater intrusion from the Persian Gulf to the Shatt Al-Arab River, which is the main source of water supply for Al-Thagher city. High salt concentrations in wastewater lead to reduce the performance of biological treatment due to the negative effects of salt on microorganisms [1].

The measured total suspended solids (TSS) concentrations $(21-422 \mathrm{mg} / \mathrm{L})$ in raw wastewater varied between the medium $(120-400 \mathrm{mg} / \mathrm{L})$ and weak $(<120 \mathrm{mg} / \mathrm{L})$ range of typical wastewater concentrations. The TSS concentrations 
in 9 months were between $120-400 \mathrm{mg} / \mathrm{L}$ (medium) and were less than $120 \mathrm{mg} / \mathrm{L}$ (weak) in 14 months.

The measured concentrations of $\mathrm{NH}_{3}-\mathrm{N}(1.7-35 \mathrm{mg} / \mathrm{L})$ in raw wastewater varied between the medium $(20-75 \mathrm{mg} / \mathrm{L})$ and weak $(<20 \mathrm{mg} / \mathrm{L})$ range of typical wastewater concentrations. The $\mathrm{NH}_{3}-\mathrm{N}$ concentrations in most months were between 20-75 mg/L (medium) and were less than $20 \mathrm{mg} / \mathrm{L}$ (weak) in only seven months (Sep. 2017 to Mar. 2018).

The measured concentrations of $\mathrm{PO}_{4}-\mathrm{P}(0.3-19.8 \mathrm{mg} / \mathrm{L})$ in raw wastewater varied between the medium $(5-15 \mathrm{mg} / \mathrm{L})$ and weak $(<5 \mathrm{mg} / \mathrm{L})$ range of typical wastewater concentrations. The $\mathrm{PO}_{4}-\mathrm{P}$ concentrations in some months (Feb. 2017 to Jan. 2018) were between 5-15 mg/L (medium) and were less than $5 \mathrm{mg} / \mathrm{L}$ (weak) in other months (Feb. 2018 to Dec. 2018).

The measured concentrations of COD $(85-315 \mathrm{mg} / \mathrm{L})$ in raw wastewater varied between medium (250-1000 mg/L) and weak $(<250 \mathrm{mg} / \mathrm{L})$. The COD concentrations in most months were less than $250 \mathrm{mg} / \mathrm{L}$ (weak) and were between 250-1000 mg/L (medium) in only two months (Dec. 2017 and Nov. 2018).

The measured concentrations of BOD (39-180 mg/L) in raw wastewater varied between medium (100-300 mg/L) and weak $(<100 \mathrm{mg} / \mathrm{L})$. The BOD concentrations in most months were less than or equal to $100 \mathrm{mg} / \mathrm{L}$ (weak) and were between $100-300 \mathrm{mg} / \mathrm{L}$ (medium) in only six months (Oct. 2017 to Mar. 2018).

As shown in Table 4, the values of the BOD/COD ratio have been classified into three categories: slowly biodegradable (0.2-0.4), average biodegradable $(0.4-0.5)$ and readily biodegradable $(0.5-0.8)$. In most months, the calculated $\mathrm{BOD} / \mathrm{COD}$ ratio was equal to or greater than 0.4 (average and readily biodegradable). The BOD/COD ratio was slowly biodegradable in two months (May 2017 and Jun. 2017) and not biodegradable in two months (Apr. 2018 and Nov. 2018). However, the mean value of the BOD/ COD ratio was 0.51 , which shows the wastewater is generally readily biodegradable [37].

\subsection{Effluent characteristics}

Table 5 shows the treated water properties at the Al-Thagher WWTP. Iraqi water quality standards (IWQS) [38] are used as a basis for the water quality evaluation of the present study. The parameters for $\mathrm{T}, \mathrm{pH}, \mathrm{NH}_{3}-\mathrm{N}, \mathrm{COD}$ and BOD in the effluent (treated water) met the IWQS. The remaining parameters met the IWQS standard in some months but did not in other months. $\mathrm{PO}_{4}-\mathrm{P}$ met IWQS in most months except Feb. 2018 to Sep. and Nov. 2018 to Dec.
Table 4 BOD/COD ratio and biodegradability of organic matter [1]

\begin{tabular}{lcccc}
\hline \multirow{2}{*}{ Ratio } & \multicolumn{4}{c}{ Biodegradable of organic matter } \\
& Not & Slowly & Average & Readily \\
\hline BOD/COD & $<0.2$ & $0.2-0.4$ & $0.4-0.5$ & $0.5-0.8$ \\
\hline
\end{tabular}

2018. $\mathrm{Cl}^{-1}$ met IWQS in most months except Mar. 2017, Dec. 2017, Apr. 2018, Nov. 2018 and Dec. 2018. $\mathrm{SO}_{4}^{-2}$ did not meet IWQS in most months except Apr. 2017 to Aug. 2017 and Jul. 2018 to Sep. 2018. TSS met IWQS in most months except Feb. 2017 to Apr. 2017 and Dec. 2018. EC and TDS do not meet IWQS in most months except May 2017 to Aug. 2017 and Aug. 2018 to Sep. 2018.

Variation of the BOD/COD ratio in influent and effluent are shown in Fig. 3. In the first six months (Feb. 2017 to Jul. 2017), the BOD/COD ratio of effluent (0.39-0.46) is slightly higher than the $\mathrm{BOD} / \mathrm{COD}$ ratio of influent (0.47-0.58), which is almost constant, so the curve is horizontal during this period. For the next month (Aug. 2017), the BOD/COD ratio of effluent (0.48) and influent (0.46) were almost identical. In the following six months, the BOD/COD ratio of effluent (0.41-0.49) was lower than the BOD/COD ratio of influent (0.53-0.84), which gradually increases. In Apr. 2018, the BOD/COD ratio of effluent (0.30) slightly increased above the BOD/COD ratio of influent (0.19). In the final months of the study period, a fluctuation occurs in the curve of $\mathrm{BOD} / \mathrm{COD}$ ratio of effluent and influent, and the highest BOD/COD ratio of effluent was 1.31 in Nov. 2018.

The BOD/COD ratio naturally decreases over each stage of traditional wastewater treatment. This occurs mainly because the biodegradable fraction of organic matter, measured by the BOD, is first degraded by the present microorganisms, while the more inert fraction of organic matter is usually constant during treatment. Therefore, $\mathrm{BOD}$ tends to decrease faster than COD, and the BOD/ COD ratio decreases. However, sometimes BOD increases during treatment because of the dissolution of organic particulate matter or hydrolysis of complex organic molecules, which cause an increase in the COD. This phenomenon depends on many factors, such as the composition of the wastewater, biomass acclimation to wastewater, presence of inhibitors (like ammonia) and more. When it happens, BOD/COD ratio will increase [39].

\subsection{Water quality index (CCME WQI)}

It is necessary to represent the effluent quality by a single WQI number because some parameters were met, and other parameters did not meet the IWQS, as shown in Section 3.2. 
Table 5 Effluent wastewater characteristics of the Al-Thagher WWTP by month

\begin{tabular}{|c|c|c|c|c|c|c|c|c|c|c|c|c|}
\hline Month & $\mathrm{T}$ & $\mathrm{pH}$ & $\mathrm{EC}$ & TDS & TSS & $\mathrm{SO}_{4}^{-2}$ & $\mathrm{Cl}^{-1}$ & $\mathrm{NH}_{3}-\mathrm{N}$ & $\mathrm{PO}_{4}-\mathrm{P}$ & COD & BOD & $\mathrm{BOD} / \mathrm{COD}$ \\
\hline Feb-17 & $16.3 \pm 2.9$ & $6.7 \pm 0.15$ & $3178 \pm 432$ & $1598 \pm 315$ & $89 \pm 19$ & $456 \pm 132$ & $562 \pm 69$ & $5.4 \pm 1.0$ & $1.2 \pm 0.9$ & $28 \pm 10$ & $15 \pm 6$ & 0.46 \\
\hline Mar-17 & $21.7 \pm 3.8$ & $7.0 \pm 0.05$ & $3437 \pm 510$ & $2000 \pm 218$ & $93 \pm 13$ & $495 \pm 107$ & $630 \pm 103$ & $0.6 \pm 0.3$ & $1.0 \pm 0.4$ & $70 \pm 15$ & $33 \pm 6$ & 0.41 \\
\hline Apr-17 & $25.9 \pm 5.3$ & $7.1 \pm 0.11$ & $2566 \pm 513$ & $1507 \pm 231$ & $72 \pm 11$ & $371 \pm 79$ & $452 \pm 85$ & $4.2 \pm 1.2$ & $0.5 \pm 0.2$ & $69 \pm 12$ & $32 \pm 4$ & 0.4 \\
\hline May-17 & $29.6 \pm 5.4$ & $7.2 \pm 0.22$ & $1694 \pm 652$ & $1014 \pm 332$ & $41 \pm 15$ & $247 \pm 111$ & $273 \pm 86$ & $7.8 \pm 1.0$ & $0.2 \pm 0.1$ & $64 \pm 10$ & $31 \pm 5$ & 0.39 \\
\hline Jun-17 & $34.8 \pm 5.3$ & $7.1 \pm 0.08$ & $1773 \pm 362$ & $1072 \pm 217$ & $21 \pm 14$ & $252 \pm 112$ & $298 \pm 74$ & $7.4 \pm 1.5$ & $1.6 \pm 0.8$ & $39 \pm 10$ & $19 \pm 4$ & 0.39 \\
\hline Jul-17 & $37.9 \pm 4.0$ & $7.0 \pm 0.10$ & $1940 \pm 608$ & $1208 \pm 345$ & $11 \pm 5$ & $265 \pm 101$ & $322 \pm 67$ & $7.0 \pm 1.1$ & $2.9 \pm 1.4$ & $16 \pm 11$ & $10 \pm 4$ & 0.41 \\
\hline Aug-17 & $35.5 \pm 4.1$ & $7.1 \pm 0.14$ & $2131 \pm 471$ & $1416 \pm 377$ & $12 \pm 5$ & $331 \pm 134$ & $291 \pm 105$ & $7.2 \pm 1.5$ & $1.8 \pm 1.2$ & $23 \pm 12$ & $11 \pm 4$ & 0.46 \\
\hline Sep-17 & $31.2 \pm 3.5$ & $7.3 \pm 0.07$ & $2405 \pm 372$ & $1646 \pm 380$ & $15 \pm 10$ & $416 \pm 83$ & $260 \pm 111$ & $7.6 \pm 1.1$ & $0.7 \pm 0.5$ & $29 \pm 8$ & $12 \pm 4$ & 0.53 \\
\hline Oct-17 & $25.8 \pm 4.9$ & $7.3 \pm 0.24$ & $2955 \pm 511$ & $1869 \pm 410$ & $22 \pm 15$ & $462 \pm 71$ & $362 \pm 97$ & $7.9 \pm 1.1$ & $0.7 \pm 0.5$ & $26 \pm 11$ & $11 \pm 4$ & 0.61 \\
\hline Nov-17 & $20.0 \pm 4.1$ & $7.3 \pm 0.19$ & $3615 \pm 543$ & $2074 \pm 346$ & $32 \pm 17$ & $490 \pm 124$ & $553 \pm 80$ & $8.1 \pm 1.4$ & $0.7 \pm 0.4$ & $20 \pm 10$ & $8 \pm 4$ & 0.65 \\
\hline Dec-17 & $17.2 \pm 5.4$ & $7.3 \pm 0.23$ & $3936 \pm 408$ & $2164 \pm 264$ & $37 \pm 11$ & $516 \pm 76$ & $655 \pm 120$ & $8.2 \pm 1.2$ & $0.7 \pm 0.5$ & $17 \pm 13$ & $7 \pm 3$ & 0.66 \\
\hline Jan-18 & $17.7 \pm 4.2$ & $7.2 \pm 0.23$ & $3658 \pm 431$ & $2085 \pm 412$ & $32 \pm 18$ & $548 \pm 118$ & $596 \pm 78$ & $7.6 \pm 1.5$ & $3.1 \pm 1.4$ & $28 \pm 8$ & $13 \pm 6$ & 0.72 \\
\hline Feb-18 & $19.3 \pm 5.2$ & $7.1 \pm 0.19$ & $3142 \pm 559$ & $1939 \pm 369$ & $22 \pm 11$ & $577 \pm 87$ & $486 \pm 111$ & $6.4 \pm 1.6$ & $7.6 \pm 2.9$ & $48 \pm 11$ & $23 \pm 6$ & 0.84 \\
\hline Mar-18 & $22.0 \pm 4.7$ & $7.0 \pm 0.10$ & $2864 \pm 544$ & $1860 \pm 375$ & $17 \pm 8$ & $590 \pm 113$ & $428 \pm 70$ & $5.3 \pm 0.9$ & $10.0 \pm 2.6$ & $59 \pm 9$ & $29 \pm 6$ & 0.81 \\
\hline Apr-18 & $26.6 \pm 3.9$ & $7.1 \pm 0.24$ & $3388 \pm 446$ & $2234 \pm 281$ & $47 \pm 19$ & $539 \pm 132$ & $645 \pm 107$ & $4.5 \pm 1.4$ & $7.8 \pm 2.1$ & $50 \pm 14$ & $15 \pm 6$ & 0.19 \\
\hline May-18 & $26.2 \pm 5.2$ & $7.2 \pm 0.07$ & $2600 \pm 359$ & $1712 \pm 283$ & $48 \pm 19$ & $462 \pm 128$ & $478 \pm 108$ & $6.1 \pm 1.3$ & $9.9 \pm 2.8$ & $66 \pm 13$ & $12 \pm 4$ & 0.4 \\
\hline Jun-18 & $32.7 \pm 2.9$ & $7.3 \pm 0.08$ & $2476 \pm 507$ & $1556 \pm 377$ & $52 \pm 19$ & $427 \pm 127$ & $445 \pm 84$ & $7.6 \pm 1.0$ & $9.9 \pm 1.7$ & $60 \pm 12$ & $28 \pm 6$ & 0.55 \\
\hline Jul-18 & $31.7 \pm 4.0$ & $7.2 \pm 0.04$ & $2571 \pm 452$ & $1750 \pm 396$ & $18 \pm 9$ & $392 \pm 134$ & $421 \pm 87$ & $6.8 \pm 1.1$ & $8.7 \pm 1.7$ & $30 \pm 8$ & $22 \pm 4$ & 0.58 \\
\hline Aug-18 & $33.8 \pm 4.2$ & $7.4 \pm 0.15$ & $2311 \pm 528$ & $1218 \pm 267$ & $44 \pm 12$ & $322 \pm 81$ & $410 \pm 65$ & $5.9 \pm 1.6$ & $7.1 \pm 3.1$ & $36 \pm 9$ & $20 \pm 4$ & 0.61 \\
\hline Sep-18 & $30.9 \pm 3.5$ & $6.2 \pm 0.18$ & $1851 \pm 547$ & $1146 \pm 249$ & $11 \pm 7$ & $310 \pm 72$ & $314 \pm 89$ & $3.8 \pm 1.4$ & $7.1 \pm 2.4$ & $18 \pm 8$ & $11 \pm 4$ & 0.46 \\
\hline Oct-18 & $23.9 \pm 3.4$ & $7.0 \pm 0.23$ & $2553 \pm 652$ & $1560 \pm 287$ & $45 \pm 14$ & $435 \pm 115$ & $562 \pm 74$ & $1.3 \pm 0.9$ & $0.1 \pm 0.1$ & $49 \pm 14$ & $20 \pm 4$ & 0.43 \\
\hline Nov-18 & $19.6 \pm 2.8$ & $7.3 \pm 0.05$ & $4427 \pm 517$ & $3126 \pm 246$ & $50 \pm 19$ & $954 \pm 85$ & $780 \pm 75$ & $4.2 \pm 1.5$ & $7.1 \pm 2.9$ & $15 \pm 7$ & $20 \pm 6$ & 0.19 \\
\hline Dec-18 & $15.6 \pm 3.4$ & $7.2 \pm 0.05$ & $4680 \pm 434$ & $2764 \pm 234$ & $61 \pm 15$ & $837 \pm 131$ & $801 \pm 103$ & $3.8 \pm 1.2$ & $10.8 \pm 2.4$ & $50 \pm 10$ & $20 \pm 5$ & 0.51 \\
\hline Ave. & 25.9 & 7.1 & 2876 & 1762 & 39 & 465 & 479 & 5.9 & 4.4 & 40 & 18 & 0.50 \\
\hline $\mathrm{SD}( \pm)$ & 6.8 & 0.3 & 822 & 517 & 24 & 170 & 157 & 2.1 & 3.9 & 19 & 8 & 0.21 \\
\hline Max & 37.9 & 7.4 & 4680 & 3126 & 93 & 954 & 801 & 8.2 & 10.8 & 70 & 33 & 1.31 \\
\hline Min & 15.6 & 6.2 & 1694 & 1014 & 11 & 247 & 260 & 0.6 & 0.1 & 15 & 7 & 0.18 \\
\hline IWQS & $16-32$ & $6-9$ & 2500 & 1500 & 60 & 400 & 600 & 10 & 5 & 100 & 40 & \\
\hline
\end{tabular}

Note: 1) All values (mean $\pm \mathrm{SD}$ ) are expressed in $\mathrm{mg} / \mathrm{L}(\mathrm{ppm})$ except $\mathrm{pH}$ (dimensionless), $\mathrm{EC}(\mu \mathrm{s} / \mathrm{cm})$ and temperature $\left.\left({ }^{\circ} \mathrm{C}\right) .2\right)$ Shaded values in grey are indicted that these values did not meet IWQS

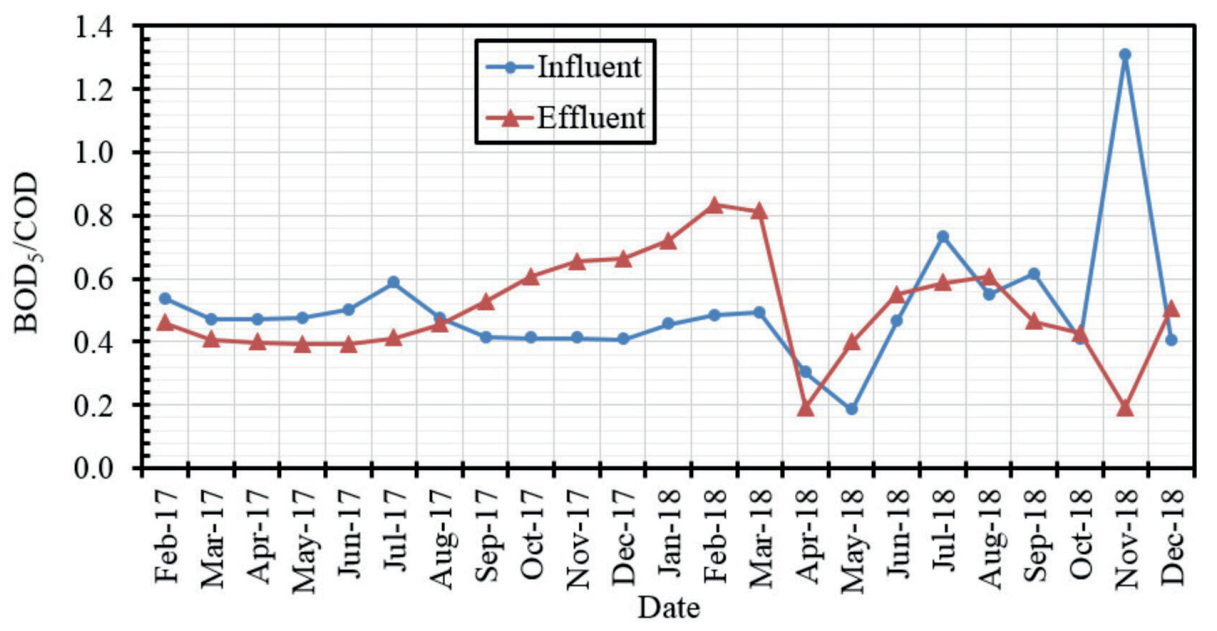

Fig. 3 Variation of BOD/COD ratio in influent and effluent 
The CCME WQI is the most reliable and adaptable in terms of the form and amount of water quality variables to be evaluated, the time of application, the accuracy of the selection criterion, the tolerance for incomplete tests, and the kind of aquatic ecosystem $[17,19]$. Therefore, CCME WQI was used in this study to evaluate the water quality of effluent. The CCME WQI mathematical formula is shown below $[17,19]$.

CCME WQI $=100-\left(\frac{\sqrt{F_{1}^{2}+F_{2}^{2}+F_{3}^{2}}}{1.732}\right)$

The CCME WQI is based on selecting parameters and setting objectives for each parameter. The index calculates three factors based on these objectives: the scope factor $\left(\mathrm{F}_{1}\right)$ represents the number of parameters that fail their objective during the index period (Eq. (2)), the frequency factor $\left(\mathrm{F}_{2}\right)$ represents the proportion of samples that fail their objectives during the index period (Eq. (3)), and the amplitude factor $\left(\mathrm{F}_{3}\right)$ represents the relative magnitude of any failures during the index period (Eqs. (4) and (5)). Thus two important environmental aspects, the frequency and severity of adverse conditions, are included in the calculation of the CCME WQI [19].

$$
\begin{aligned}
& F_{1}=\left(\frac{\text { Number of failed variables }}{\text { Total number of variables }}\right) \times 100 \\
& F_{2}=\left(\frac{\text { Number of failed tests }}{\text { Total number of tests }}\right) \times 100 \\
& \left.n s e=\frac{\sum_{i=1}^{n}\left(\frac{\text { Failed Test Value }}{i}\right)-1}{\text { Objective }_{i}}\right) \\
& F_{3}=\left(\frac{n \text { Number of Test }}{0.01 \text { nse }+0.01}\right)
\end{aligned}
$$

The CCME WQI calculations were conducted using CCME WQI calculator 2.0 software. This software has been downloaded from the website for the Canadian Council for Ministers of the Environment. The calculated value of CCME WQI is presented in Table 6 [19].

The effluent parameters of the Al-Thagher WWTP between February 2017 and December 2018 were used to determine the effluent CCME WQI. The following parameters were used to calculate the index: $\mathrm{pH}, \mathrm{EC}, \mathrm{TDS}, \mathrm{TSS}$, $\mathrm{Cl}^{-1}, \mathrm{SO}_{4}^{-2}, \mathrm{NH}_{3}-\mathrm{N}, \mathrm{COD}, \mathrm{BOD}$, Temp., and $\mathrm{PO}_{4}-\mathrm{P}$. The water quality parameters were determined according to the IQWS, which is listed in the last row in Table 5. The calculation details of CCME WQI are presented in Table 7. The estimated CCME WQI value was 51.8. The water quality was graded as "Marginal", which means the water quality of the effluent was frequently threatened and impaired, and conditions often depart from natural levels.

\subsection{Wastewater treatment performance}

The influent and effluent characteristics of the Al-Thagher WWTP are illustrated graphically in Fig. 4. Concentrations of COD, BOD, TSS and $\mathrm{NH}_{3}-\mathrm{N}$ in the effluent during all the studied months are less than their concentration in influent, as shown in Figs. 4(a), 4(b), 4(c), and 4(d), respectively. The concentrations of the remaining parameters $\left(\mathrm{PO}_{4}-\mathrm{P}, \mathrm{Cl}^{-1}, \mathrm{EC}, \mathrm{TDS}, \mathrm{SO}_{4}^{-2}\right.$, and $\left.\mathrm{pH}\right)$ in effluent fluctu-

\begin{tabular}{|c|c|c|}
\hline $\begin{array}{l}\text { CCME } \\
\text { WQI }\end{array}$ & Ranks & Water Quality Characteristics \\
\hline $95-100$ & Excellent & $\begin{array}{l}\text { Water quality is protected with a virtual } \\
\text { absence of threat or impairment; conditions } \\
\text { very close to natural or pristine levels. }\end{array}$ \\
\hline $80-94$ & Good & $\begin{array}{l}\text { Water quality is protected with only a minor } \\
\text { degree of threat or impairment; conditions } \\
\text { rarely depart from natural or desirable levels. }\end{array}$ \\
\hline $65-79$ & Fair & $\begin{array}{l}\text { Water quality is usually protected but } \\
\text { occasionally threatened or impaired; } \\
\text { conditions sometimes depart from natural or } \\
\text { desirable levels. }\end{array}$ \\
\hline $45-64$ & Marginal & $\begin{array}{c}\text { water quality is frequently threatened or } \\
\text { impaired; conditions often depart from } \\
\text { natural or desirable levels }\end{array}$ \\
\hline $0-44$ & Poor & $\begin{array}{c}\text { Water quality is almost always threatened } \\
\text { or impaired; conditions usually depart from } \\
\text { natural or desirable levels. }\end{array}$ \\
\hline
\end{tabular}
ated above and below the influent concentration, as shown in Figs. 4(e), 4(f), 4(g), 4(h), 4(i), and 4(j), respectively.

Table 6 Classification of CCME WQI values [19]

Table 7 Details of CCME WQI calculations for effluent quality of the Al-Thagher WWTP

\begin{tabular}{lc}
\hline Item & Value \\
\hline Total No. of parameters & 11 \\
Total No. of tests & 253 \\
No. of failed parameters & 8 \\
No. of failed tests & 91 \\
nse & 0.24 \\
$\mathrm{~F}_{1}$ & 72.73 \\
$\mathrm{~F}_{2}$ & 35.97 \\
$\mathrm{~F}_{3}$ & 19.68 \\
CCME WQI & 51.80 \\
\hline
\end{tabular}




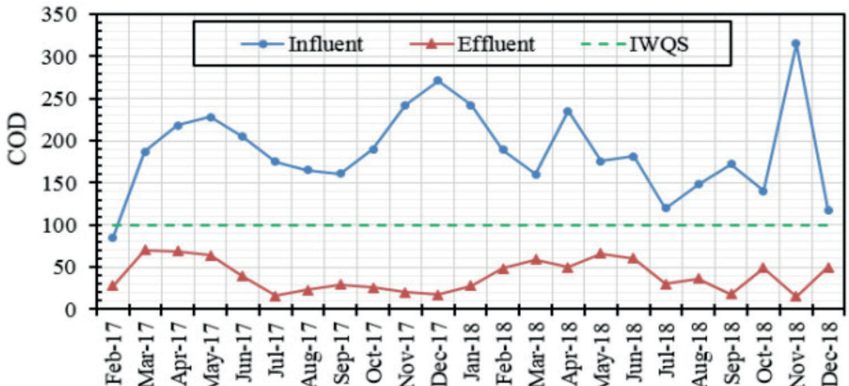

(a)

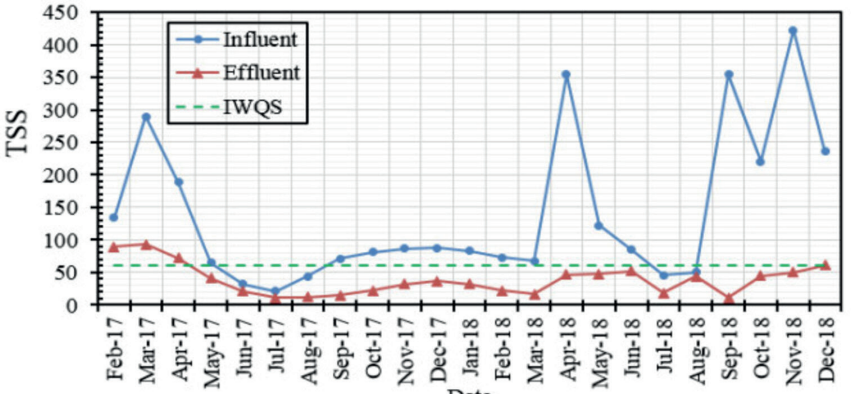

(c)

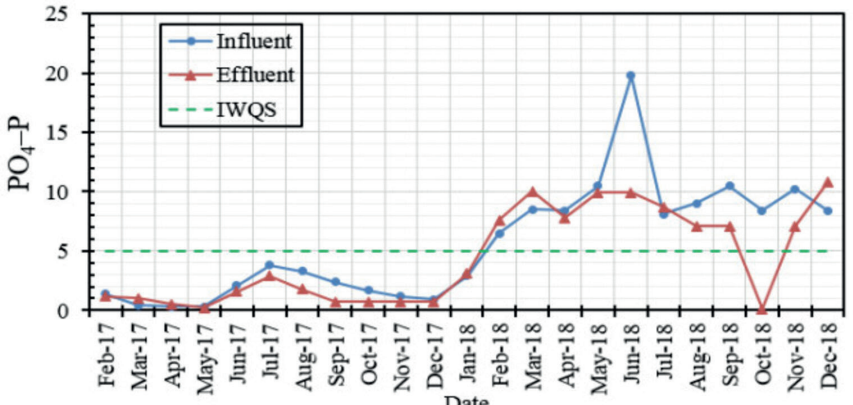

(e)

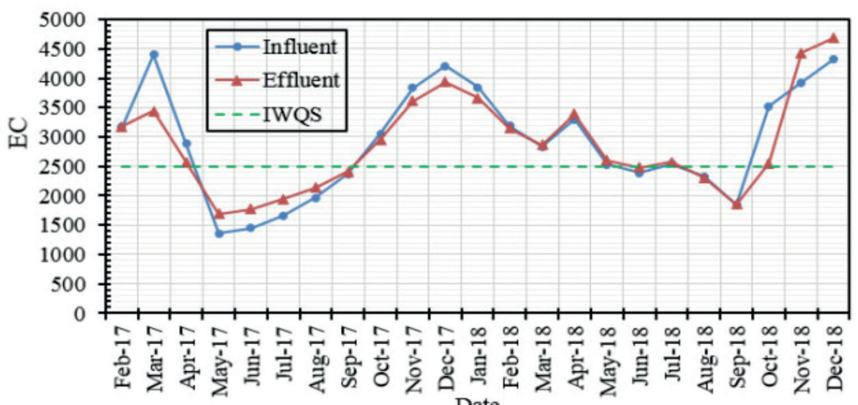

(g)

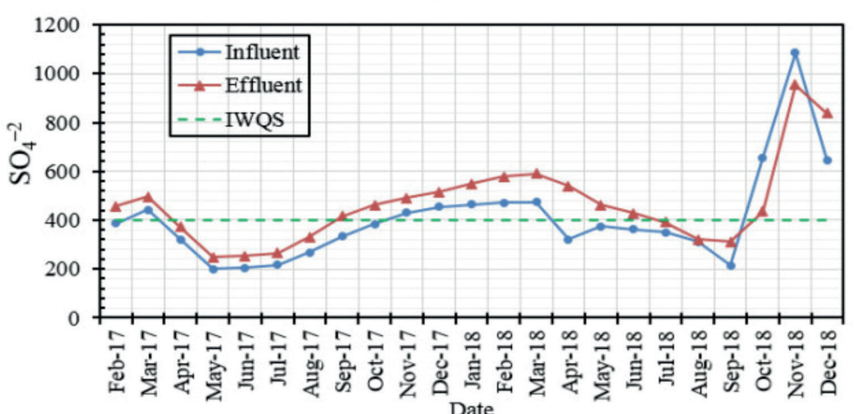

(i)

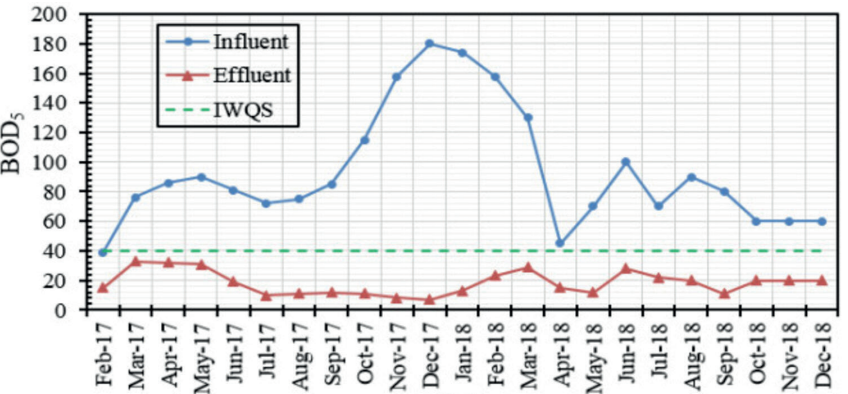

(b)

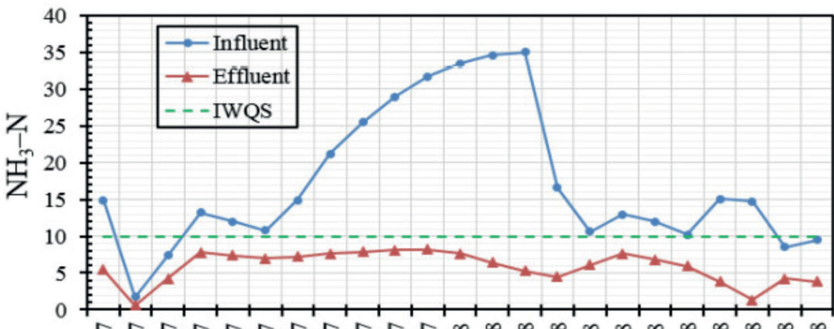

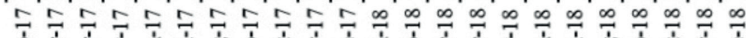

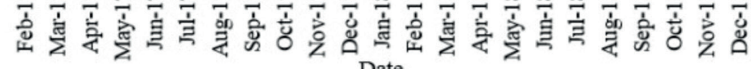

(d)

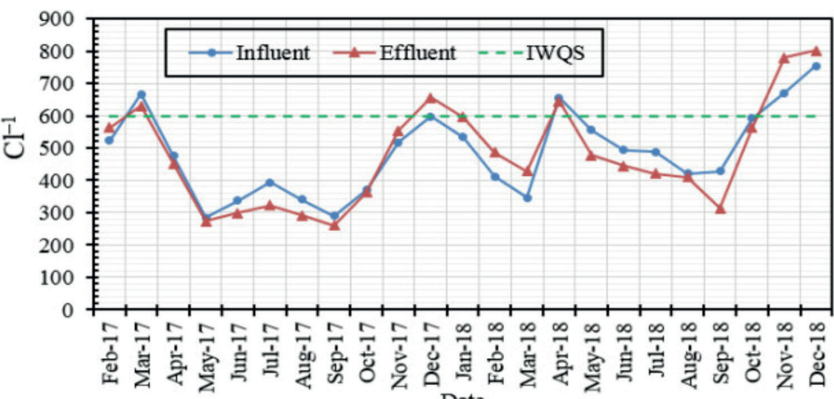

(f)

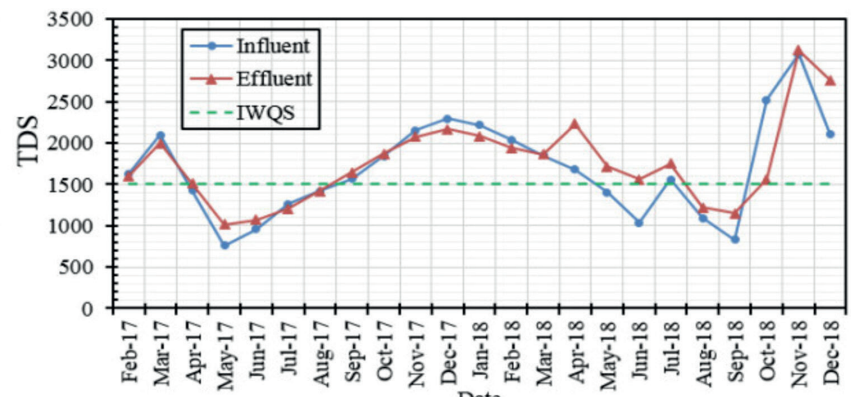

(h)

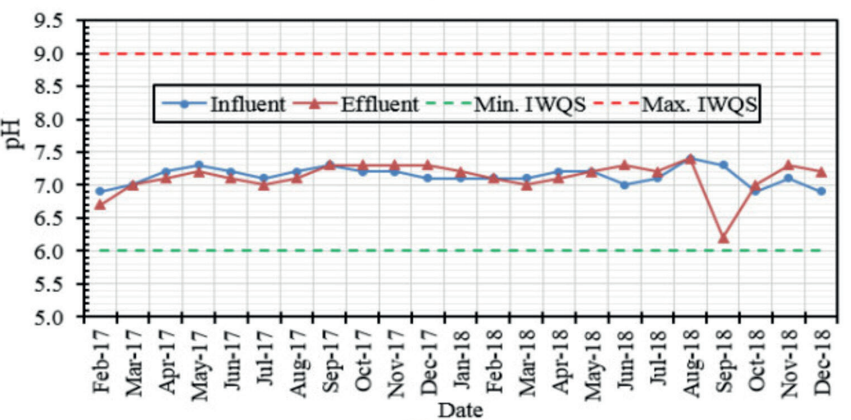

(j)

Fig. 4 Influent and effluent characteristics of the Al-Thagher WWTP. (a) COD, (b) BOD, (c) TSS, (d) $\mathrm{NH}_{3}-\mathrm{N}$, (e) $\mathrm{PO}_{4}-\mathrm{P}$, (f) $\mathrm{Cl}^{-1}$, (g) EC, (h) TDS, (i) $\mathrm{SO}_{4}^{-2}$ and (j) $\mathrm{pH}$ 
Table 8 lists the removal efficiency of the main parameters for the Al-Thagher WWTP. In Table 8, the positive sign indicates that pollutant removal is efficient. The negative sign indicates that there is no efficiency of pollutant removal or there is an increase in the concentration of the pollutant in the effluent of the plant. $\mathrm{PO}_{4}-\mathrm{P}$ removals in 16 months were positive and negative in the other seven months. The positive removal of $\mathrm{PO}_{4}-\mathrm{P}$ were ranged from 5.71 to $98.81 \%$. $\mathrm{Cl}^{-1}$ removals in 15 months were positive and negative in the other eight months. The positive removal of $\mathrm{Cl}^{-1}$ ranged from 1.68 to $26.64 \%$. EC removal was negative in 14 months and positive in the other nine months. The positive removal of EC ranged from 0.73 to $27.47 \%$. TDS removal was negative in 15 months and positive in the other eight months. The positive removal of TDS was ranged from 1.72 to $38.1 \%$. $\mathrm{SO}_{4}^{-2}$ removal was negative in 21 months and positive in the other two months. The positive removal of $\mathrm{SO}_{4}^{-2}$ ranged from 12.07 to $33.59 \%$.
The average removal efficiencies of some parameters (COD, BOD, TSS, and $\mathrm{NH}_{3}-\mathrm{N}$ ) were greater than $50 \%$, and other parameters $\left(\mathrm{PO}_{4}-\mathrm{P}, \mathrm{Cl}^{-1}, \mathrm{EC}, \mathrm{TDS}\right.$, and $\left.\mathrm{SO}_{4}^{-2}\right)$ had removal efficiencies less than $50 \%$. Therefore, the plant was efficient for removing COD, BOD, TSS, and $\mathrm{NH}_{3}-\mathrm{N}$ and not efficient for removing $\mathrm{PO}_{4}-\mathrm{P}, \mathrm{Cl}^{-1}$, $\mathrm{EC}$, TDS, and $\mathrm{SO}_{4}^{-2}$.

\subsection{T-test of removal efficiency}

The summary of the Al-Thagher WWTP performance in terms of the t-test and removal efficiency is listed in Table 9 and shown in Fig. 5. In general, there is a significant removal efficiency when the t-test result is less than or equal to 0.05 $(\mathrm{t} \leq 0.05)$, and vice versa. The results show a significant removal efficiency $(\mathrm{t}<0.05)$ of BOD, $\mathrm{COD}, \mathrm{NH}_{3}-\mathrm{N}$ and TSS; these parameters had high removal percentages compared to other parameters. In contrast, there are low or negative removal efficiencies for $\mathrm{PO}_{4}-\mathrm{P}, \mathrm{SO}_{4}{ }^{-2}$, TDS, $\mathrm{EC}$, and $\mathrm{Cl}^{-1}$, and the t-test results show no significant difference

Table 8 Monthly average removal efficiency of the main parameters for the effluent of the Al-Thagher WWTP

\begin{tabular}{|c|c|c|c|c|c|c|c|c|c|}
\hline \multirow{2}{*}{ Month } & \multicolumn{9}{|c|}{ Removal (\%) } \\
\hline & COD & BOD & TSS & $\mathrm{NH}_{3}-\mathrm{N}$ & $\mathrm{PO}_{4}-\mathrm{P}$ & $\mathrm{Cl}^{-1}$ & $\mathrm{EC}$ & TDS & $\mathrm{SO}_{4}^{-2}$ \\
\hline Feb-17 & 67.06 & 61.54 & 33.58 & 63.76 & 14.29 & -7.46 & -0.38 & 1.72 & -18.13 \\
\hline Mar-17 & 62.57 & 56.58 & 67.93 & 64.71 & -150.00 & 5.55 & 21.82 & 4.58 & -12.24 \\
\hline Apr-17 & 68.35 & 62.79 & 61.90 & 43.24 & -66.67 & 4.84 & 10.87 & -5.68 & -15.94 \\
\hline May-17 & 71.93 & 65.56 & 36.92 & 40.91 & 33.33 & 3.87 & -24.38 & -34.13 & -24.12 \\
\hline Jun-17 & 80.98 & 76.54 & 34.38 & 38.33 & 23.81 & 11.83 & -22.53 & -12.02 & -23.53 \\
\hline Jul-17 & 90.86 & 86.11 & 47.62 & 35.19 & 23.68 & 18.07 & -17.01 & 4.13 & -22.12 \\
\hline Aug-17 & 86.06 & 85.33 & 72.73 & 51.68 & 45.45 & 14.66 & -8.50 & 0.00 & -23.97 \\
\hline Sep-17 & 81.99 & 85.88 & 78.87 & 64.15 & 70.83 & 10.34 & -1.35 & -5.11 & -24.92 \\
\hline Oct-17 & 86.32 & 90.43 & 72.84 & 69.02 & 58.82 & 2.16 & 3.18 & -1.58 & -20.31 \\
\hline Nov-17 & 91.74 & 94.94 & 63.22 & 72.07 & 41.67 & -6.76 & 5.64 & 3.53 & -14.22 \\
\hline Dec-17 & 93.73 & 96.11 & 57.95 & 74.13 & 22.22 & -9.53 & 6.37 & 5.83 & -13.41 \\
\hline Jan-18 & 88.43 & 92.53 & 61.45 & 77.31 & -6.90 & -11.82 & 4.94 & 6.08 & -17.85 \\
\hline Feb-18 & 74.60 & 85.44 & 69.86 & 81.50 & -16.92 & -17.96 & 1.44 & 5.09 & -22.51 \\
\hline Mar-18 & 63.13 & 77.69 & 75.00 & 84.86 & -17.65 & -23.34 & -1.13 & -0.43 & -24.74 \\
\hline Apr-18 & 78.72 & 66.67 & 86.72 & 72.89 & 7.14 & 1.68 & -2.60 & -33.29 & -68.44 \\
\hline May-18 & 62.50 & 82.86 & 60.66 & 42.45 & 5.71 & 13.87 & -2.89 & -22.11 & -23.20 \\
\hline Jun-18 & 66.85 & 72.00 & 38.82 & 41.54 & 50.00 & 9.92 & -3.60 & -50.19 & -17.63 \\
\hline Jul-18 & 75.00 & 68.57 & 60.87 & 43.33 & -7.41 & 13.91 & -1.34 & -12.32 & -12.00 \\
\hline Aug-18 & 75.68 & 77.78 & 12.00 & 42.16 & 21.11 & 2.61 & 0.73 & -11.54 & -3.21 \\
\hline Sep-18 & 89.53 & 86.25 & 96.89 & 74.83 & 32.38 & 26.64 & -0.22 & -38.07 & -45.54 \\
\hline Oct-18 & 65.00 & 66.67 & 79.55 & 91.16 & 98.81 & 4.91 & 27.47 & 38.10 & 33.59 \\
\hline Nov-18 & 95.24 & 66.67 & 88.15 & 50.59 & 30.39 & -16.42 & -12.82 & -1.82 & 12.07 \\
\hline Dec-18 & 57.63 & 66.67 & 74.15 & 60.00 & -28.57 & -6.37 & -8.33 & -31.12 & -29.77 \\
\hline Max. & 95.24 & 96.11 & 96.89 & 91.16 & 98.81 & 26.64 & 27.47 & 38.10 & 33.59 \\
\hline Min. & 57.63 & 56.58 & 12.00 & 35.19 & -150.00 & -23.34 & -24.38 & -50.19 & -68.44 \\
\hline Average & 77.12 & 77.03 & 62.26 & 59.99 & 12.42 & 1.97 & -1.07 & -8.28 & -18.79 \\
\hline $\mathrm{SD}( \pm)$ & 11.61 & 11.76 & 20.47 & 16.99 & 49.95 & 12.63 & 11.99 & 19.33 & 18.57 \\
\hline
\end{tabular}


Table 9 Minimum, maximum, average, standard deviation (SD) and t-test for the removal rate efficiency of the Al-Thagher WWTP

\begin{tabular}{|c|c|c|c|c|c|}
\hline \multirow{2}{*}{ Parameter } & \multicolumn{4}{|c|}{ Removal Efficiency \% } & \multirow{2}{*}{ t-test } \\
\hline & Average & Max. & Min. & $\mathrm{SD}( \pm)$ & \\
\hline COD & 77.12 & 95.24 & 57.63 & 11.61 & $0.437 \times 10^{-12}$ \\
\hline BOD & 77.03 & 96.11 & 56.58 & 11.76 & $0.595 \times 10^{-8}$ \\
\hline $\mathrm{NH}_{3}-\mathrm{N}$ & 59.99 & 91.16 & 35.19 & 16.99 & $0.109 \times 10^{-4}$ \\
\hline TSS & 62.26 & 96.89 & 12.00 & 20.47 & $0.447 \times 10^{-3}$ \\
\hline $\mathrm{SO}_{4}^{-2}$ & -18.79 & 33.59 & -68.44 & 18.57 & 0.284 \\
\hline $\mathrm{PO}_{4}-\mathrm{P}$ & 12.42 & 98.81 & -150.00 & 49.95 & 0.359 \\
\hline TDS & -8.28 & 38.10 & -50.19 & 19.33 & 0.646 \\
\hline $\mathrm{EC}$ & -1.07 & 27.47 & -24.38 & 11.99 & 0.900 \\
\hline $\mathrm{Cl}^{-1}$ & 1.97 & 26.64 & -23.34 & 12.63 & 0.902 \\
\hline
\end{tabular}

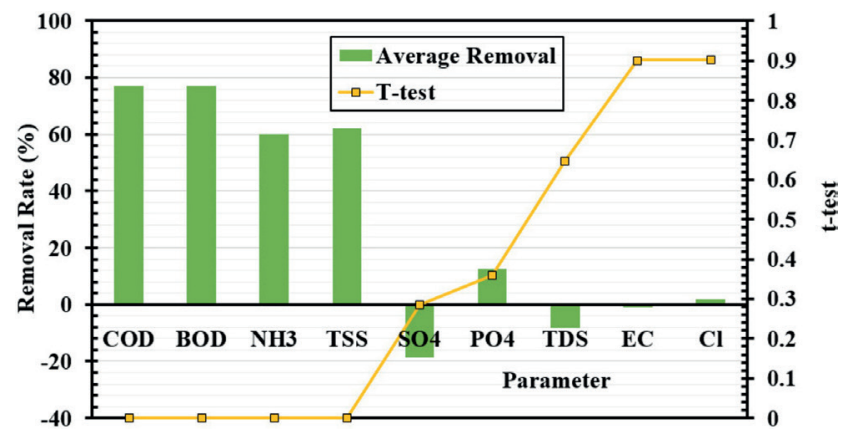

Fig. 5 Average and t-test for the removal rate efficiency of the AlThagher WWTP

in efficiency $(\mathrm{t}>0.05)$. However, there is no removal efficiency for these parameters, but increasing their concentrations in the effluent was due to the mixing of influent with the previous higher concentration wastewater remaining in the aeration tank or settling tank.

The results indicate that the wastewater treatment is failing. These factors include the consistency of the return activated sludge (RAS) or inadequate aeration, which prevents microorganisms from biodegrading organic matter. In addition, the secondary sedimentation tank cannot work efficiently because it does not have enough time to settle sludge. As a result, the sewage treatment process needs to be operationally improved. In general, surface water bodies are in grave danger due to indiscriminate discharge of contaminated effluents from inefficient treatment and sewage activities.

\subsection{Correlation and linear regression}

Knowing the correlation between sewage treatment parameters can facilitate rapid monitoring of the sewage treatment process. The correlation coefficient $(\mathrm{R})$ was used to explain the type of relationship (positive or negative) between each two of the studied parameters. The coefficient of determination $\left(R^{2}\right)$ was used to determine the strength of the relationship between each two of the studied parameters, as shown in Table 10. Linear regression equations for very strong, strong, and moderate correlations between the studied parameters were established. The linear regression equations between parameters are very important, especially those between a parameter that requires a long measuring time and another parameter that requires a shorter time and less effort. If the relationship between the two is known, then the parameter that requires less effort can be tracked, and the status of the parameter that requires more time can be predicted with reasonable accuracy.

The determination coefficients $\left(\mathrm{R}^{2}\right)$ of the studied parameters for influent wastewater are shown in Table 11. TDS has a strong correlation with $\mathrm{SO}_{4}^{-2}\left(\mathrm{R}^{2}=0.76\right)$ and

Table 10 Strength of association correlation according to the value of $\mathrm{R}^{2}$

\begin{tabular}{lcc}
\hline value & Value of $\mathrm{R}^{2}$ & Strength of association \\
\hline $0 \leq \mathrm{R}^{2}<0.25$ & $0.00-0.24$ & No correlation \\
$0.25 \leq \mathrm{R}^{2}<0.50$ & $0.25-0.49$ & Weak correlation \\
$0.50 \leq \mathrm{R}^{2}<0.75$ & $0.50-0.74$ & Moderate correlation \\
$0.75 \leq \mathrm{R}^{2}<0.90$ & $0.75-0.89$ & Strong correlation \\
$0.90 \leq \mathrm{R}^{2}<1$ & $0.90-0.99$ & Very strong correlation \\
$\mathrm{R}^{2}=1$ & 1.00 & Perfect correlation \\
\hline
\end{tabular}

Table 11 Determination coefficient $\left(\mathrm{R}^{2}\right)$ among the parameters of influent wastewater

\begin{tabular}{|c|c|c|c|c|c|c|c|c|c|}
\hline & COD & BOD & $\mathrm{SO}_{4}^{-2}$ & $\mathrm{Cl}^{-1}$ & TDS & TSS & $\mathrm{EC}$ & $\mathrm{NH}_{3}-\mathrm{N}$ & $\mathrm{PO}_{4}-\mathrm{P}$ \\
\hline COD & 1.00 & 0.18 & 0.09 & 0.02 & 0.11 & 0.12 & 0.05 & 0.04 & 0.02 \\
\hline BOD & & 1.00 & 0.00 & 0.03 & 0.05 & 0.13 & 0.07 & 0.67 & 0.05 \\
\hline $\mathrm{SO}_{4}^{-2}$ & & & 1.00 & 0.39 & 0.76 & 0.26 & 0.48 & 0.00 & 0.06 \\
\hline $\mathrm{Cl}^{-1}$ & & & & 1.00 & 0.38 & 0.41 & 0.64 & 0.06 & 0.05 \\
\hline TDS & & & & & 1.00 & 0.14 & 0.75 & 0.08 & 0.01 \\
\hline TSS & & & & & & 1.00 & 0.17 & 0.12 & 0.08 \\
\hline $\mathrm{EC}$ & & & & & & & 1.00 & 0.04 & 0.01 \\
\hline $\mathrm{NH}_{3}-\mathrm{N}$ & & & & & & & & 1.00 & 0.02 \\
\hline $\mathrm{PO}_{4}-\mathrm{P}$ & & & & & & & & & 1.00 \\
\hline
\end{tabular}


$\mathrm{EC}\left(\mathrm{R}^{2}=0.75\right) \cdot \mathrm{Cl}^{-1}$ and BOD have a moderate correlation with $\mathrm{EC}\left(\mathrm{R}^{2}=0.64\right)$ and $\mathrm{NH}_{3}-\mathrm{N}\left(\mathrm{R}^{2}=0.67\right)$, respectively. The remaining linear relationships between parameters had a weak correlation. The intercepts (a) and slopes (b) of the linear regression equations $(\mathrm{Y}=\mathrm{a}+\mathrm{b} \mathrm{X})$ for strong and moderate correlation between these parameters (X, Y) are listed in Table 12. These linear relationships all had a positive correlation $(+\mathrm{R})$.

The determination coefficients $\left(\mathrm{R}^{2}\right)$ of the studied effluent parameters are shown in Table 13. The present study reveals a very strong correlation $\left(\mathrm{R}^{2}=0.92\right)$ for the linear relationship of $\mathrm{SO}_{4}^{-2}$ with TDS. There are strong correlations $\left(\mathrm{R}^{2}=0.90,0.85\right.$, and 0.81$)$ for the linear relationships of TDS with $\mathrm{EC}, \mathrm{Cl}^{-1}$ with $\mathrm{EC}$, and $\mathrm{SO}_{4}^{-2}$ with $\mathrm{EC}$, respectively. There is a moderate correlation $\left(\mathrm{R}^{2}=0.74,0.69\right.$, and 0.60 ) for the linear relationship of $\mathrm{Cl}^{-1}$ with TDS, $\mathrm{Cl}^{-1}$ with $\mathrm{SO}_{4}^{-2}$, and BOD with $\mathrm{COD}$, respectively. The remaining linear relationships between other parameters had a weak correlation. The intercepts (a) and slopes (b) of the linear regression equations $(\mathrm{Y}=\mathrm{a}+\mathrm{b} \mathrm{X})$ for strong and moderate correlations between these parameters $(\mathrm{X}, \mathrm{Y})$ are listed in Table 14. These linear relationships all had a positive correlation $(+\mathrm{R})$.

Table 12 Linear regression equations for strong and moderate correlation among the parameters of influent wastewater

\begin{tabular}{|c|c|c|c|c|c|c|}
\hline \multirow{2}{*}{$\begin{array}{l}\text { Influent } \\
\text { (Y) }\end{array}$} & \multirow{2}{*}{$\begin{array}{l}\text { Influent } \\
\text { (X) }\end{array}$} & \multirow{2}{*}{$\mathrm{R}$} & \multirow{2}{*}{$\mathrm{R}^{2}$} & \multirow{2}{*}{ Evaluation } & \multicolumn{2}{|c|}{$\begin{array}{c}\text { Linear Regression } \\
\text { equation } \mathrm{Y}=\mathrm{a}+\mathrm{b} \mathrm{X}\end{array}$} \\
\hline & & & & & $\begin{array}{l}\text { Intercept } \\
\text { (a) }\end{array}$ & $\begin{array}{l}\text { Slope } \\
\text { (b) }\end{array}$ \\
\hline $\mathrm{SO}_{4}^{-2}$ & TDS & 0.87 & 0.76 & $\begin{array}{c}\text { Strong } \\
\text { Correlation }\end{array}$ & -79.95 & 0.29 \\
\hline TDS & $\mathrm{EC}$ & 0.86 & 0.75 & $\begin{array}{c}\text { Strong } \\
\text { Correlation }\end{array}$ & 119.53 & 0.54 \\
\hline $\mathrm{Cl}^{-1}$ & $\mathrm{EC}$ & 0.80 & 0.64 & $\begin{array}{l}\text { Moderate } \\
\text { correlation }\end{array}$ & 153.77 & 0.11 \\
\hline BOD & $\mathrm{NH}_{3}-\mathrm{N}$ & 0.82 & 0.67 & $\begin{array}{l}\text { Moderate } \\
\text { correlation }\end{array}$ & 35.04 & 3.41 \\
\hline
\end{tabular}

The determination coefficients $\left(\mathrm{R}^{2}\right)$ between the studied parameters of influent and effluent are shown in Table $15 . \mathrm{SO}_{4}^{-2}$ in the effluent has a strong correlation with $\mathrm{SO}_{4}^{-2}\left(\mathrm{R}^{2}=0.79\right)$ in the influent, and it has a moderate correlation with $\mathrm{Cl}^{-1}\left(\mathrm{R}^{2}=0.58\right)$, TDS $\left(\mathrm{R}^{2}=0.69\right)$, and $\mathrm{EC}\left(\mathrm{R}^{2}=0.57\right)$ in the influent. $\mathrm{Cl}^{-1}$ in the effluent has a strong correlation with $\mathrm{Cl}^{-1}\left(\mathrm{R}^{2}=0.87\right)$ in the influent, and it has a moderate correlation with TDS $\left(\mathrm{R}^{2}=0.54\right)$ and EC $\left(R^{2}=0.61\right)$ in the influent. TDS in the effluent has a moderate correlation with TDS $\left(R^{2}=0.70\right), E C\left(R^{2}=0.68\right)$, $\mathrm{SO}_{4}^{-2}\left(\mathrm{R}^{2}=0.64\right)$, and $\mathrm{Cl}^{-1}\left(\mathrm{R}^{2}=0.58\right)$ in the influent. EC in the effluent has a strong correlation with $\mathrm{EC}\left(\mathrm{R}^{2}=0.85\right)$ and $\mathrm{Cl}^{-1}\left(\mathrm{R}^{2}=0.80\right)$ in the influent, and it has a moderate correlation with TDS $\left(\mathrm{R}^{2}=0.69\right)$ and $\mathrm{SO}_{4}^{-2}\left(\mathrm{R}^{2}=0.58\right)$ in the influent. TSS in the effluent has a moderate correlation with $\mathrm{NH}_{3}-\mathrm{N}\left(\mathrm{R}^{2}=0.50\right)$ and $\mathrm{PO}_{4}^{-2}\left(\mathrm{R}^{2}=0.52\right)$ in the influent. $\mathrm{PO}_{4}-\mathrm{P}$ in the effluent has a moderate correlation with $\mathrm{PO}_{4}-\mathrm{P}\left(\mathrm{R}^{2}=0.66\right)$ in the influent. The remaining linear relationships between other parameters had a weak correlation. The intercepts (a) and slopes (b) of the linear regression equations $(\mathrm{Y}=\mathrm{a}+\mathrm{bX})$ for strong and moderate correlations between these parameters $(\mathrm{X}, \mathrm{Y})$ are listed in Table 16. These linear relationships all have a positive correlation $(+\mathrm{R})$, except the relationship of TSS with $\mathrm{NH}_{3}-\mathrm{N}$ is negative $(-R)$.

\section{Conclusions}

The following significant conclusions can be drawn from the present evaluation of the Al-Thagher WWTP.

- The effluent (treated water) of the Al-Thagher WWTP met Iraqi water quality standards in some parameters ( $\mathrm{T}, \mathrm{pH}, \mathrm{NH}_{3}-\mathrm{N}, \mathrm{COD}$ and $\mathrm{BOD}$ ), while standards for other parameters (EC, TDS, TSS, $\mathrm{SO}_{4}^{-2}, \mathrm{Cl}^{-1}$ and $\mathrm{PO}_{4}-\mathrm{P}$ ) have not been met.

- The CCME WQI value of treated water was 51.80 and classified as "marginal", which means the water

Table 13 Determination coefficient $\left(\mathrm{R}^{2}\right)$ among the parameters of effluent wastewater

\begin{tabular}{|c|c|c|c|c|c|c|c|c|c|}
\hline & COD & BOD & $\mathrm{SO}_{4}^{-2}$ & $\mathrm{Cl}^{-1}$ & TDS & TSS & $\mathrm{EC}$ & $\mathrm{NH}_{3}-\mathrm{N}$ & $\mathrm{PO}_{4}-\mathrm{P}$ \\
\hline COD & 1.00 & 0.60 & 0.00 & 0.00 & 0.01 & 0.25 & 0.01 & 0.15 & 0.04 \\
\hline BOD & & 1.00 & 0.00 & 0.00 & 0.00 & 0.21 & 0.01 & 0.18 & 0.03 \\
\hline $\mathrm{SO}_{4}^{-2}$ & & & 1.00 & 0.69 & 0.92 & 0.08 & 0.81 & 0.08 & 0.17 \\
\hline $\mathrm{Cl}^{-1}$ & & & & 1.00 & 0.74 & 0.34 & 0.85 & 0.19 & 0.06 \\
\hline TDS & & & & & 1.00 & 0.08 & 0.90 & 0.05 & 0.09 \\
\hline TSS & & & & & & 1.00 & 0.17 & 0.30 & 0.01 \\
\hline $\mathrm{EC}$ & & & & & & & 1.00 & 0.04 & 0.04 \\
\hline $\mathrm{NH}_{3}-\mathrm{N}$ & & & & & & & & 1.00 & 0.01 \\
\hline $\mathrm{PO}_{4}-\mathrm{P}$ & & & & & & & & & 1.00 \\
\hline
\end{tabular}


quality of effluent was frequently under threat and degraded and was often not in the desired conditions.

- The average removal efficiency of the parameters in sorted descending order is COD $(77.12 \%)>$ BOD $(77.03 \%)>\operatorname{TSS}(62.26 \%)>\mathrm{NH}_{3}-\mathrm{N}(59.99 \%)>$ $\mathrm{PO}_{4}-\mathrm{P}(12.42 \%)>\mathrm{Cl}^{-1}$ (1.97\%). Meanwhile, the EC, TDS, and $\mathrm{SO}_{4}^{-2}$ parameters achieved negative average removal efficiency.

- In the influent, the determination coefficients $\left(\mathrm{R}^{2}\right)$ described a strong correlation for the linear relationships of $\mathrm{SO}_{4}^{-2}$ with TDS and TDS with EC. There is a moderate correlation for the linear relationships of $\mathrm{Cl}^{-1}$ with EC and BOD with $\mathrm{NH}_{3}-\mathrm{N}$.

- In the effluent, the determination coefficients $\left(\mathrm{R}^{2}\right)$ described a strong correlation for the linear relation-

Table 14 Linear regression equations for strong and moderate correlation among the parameters of effluent wastewater

\begin{tabular}{|c|c|c|c|c|c|c|}
\hline \multirow{2}{*}{$\begin{array}{l}\text { Effluent } \\
\text { (Y) }\end{array}$} & \multirow{2}{*}{$\begin{array}{l}\text { Effluent } \\
\text { (X) }\end{array}$} & \multirow[t]{2}{*}{$\mathrm{R}$} & \multirow[t]{2}{*}{$\mathrm{R}^{2}$} & \multirow[t]{2}{*}{ Evaluation } & \multicolumn{2}{|c|}{$\begin{array}{c}\text { Linear Regression } \\
\text { equation } \\
\mathrm{Y}=\mathrm{a}+\mathrm{b} \mathrm{X}\end{array}$} \\
\hline & & & & & $\begin{array}{l}\text { Intercept } \\
\text { (a) }\end{array}$ & $\begin{array}{l}\text { Slope } \\
\text { (b) }\end{array}$ \\
\hline BOD & COD & 0.77 & 0.60 & $\begin{array}{l}\text { Moderate } \\
\text { correlation }\end{array}$ & 5.13 & 0.33 \\
\hline $\mathrm{Cl}^{-1}$ & $\mathrm{SO}_{4}^{-2}$ & 0.83 & 0.69 & $\begin{array}{l}\text { Moderate } \\
\text { correlation }\end{array}$ & 121.28 & 0.77 \\
\hline $\mathrm{SO}_{4}^{-2}$ & TDS & 0.96 & 0.92 & $\begin{array}{l}\text { Very strong } \\
\text { correlation }\end{array}$ & -90.07 & 0.32 \\
\hline $\mathrm{Cl}^{-1}$ & TDS & 0.86 & 0.74 & $\begin{array}{l}\text { Moderate } \\
\text { correlation }\end{array}$ & 17.73 & 0.26 \\
\hline $\mathrm{SO}_{4}^{-2}$ & $\mathrm{EC}$ & 0.90 & 0.81 & $\begin{array}{c}\text { Strong } \\
\text { Correlation }\end{array}$ & -70.84 & 0.19 \\
\hline $\mathrm{Cl}^{-1}$ & $\mathrm{EC}$ & 0.92 & 0.85 & $\begin{array}{c}\text { Strong } \\
\text { Correlation }\end{array}$ & -28.69 & 0.18 \\
\hline TDS & $\mathrm{EC}$ & 0.95 & 0.90 & $\begin{array}{c}\text { Strong } \\
\text { Correlation }\end{array}$ & 43.76 & 0.60 \\
\hline
\end{tabular}

ships of $\mathrm{SO}_{4}^{-2}$ with $\mathrm{EC}, \mathrm{Cl}^{-1}$ with $\mathrm{EC}$ and TDS with EC. There is a very strong correlation for a linear relationship of $\mathrm{SO}_{4}{ }^{-2}$ with TDS and a moderate correlation for the linear relationships of BOD with $\mathrm{COD}$ and $\mathrm{Cl}^{-1}$ with $\mathrm{SO}_{4}^{-2}$.

- The determination coefficients $\left(\mathrm{R}^{2}\right)$ of each effluent-influent parameter pair varied between strong and moderate correlation. $\mathrm{Cl}^{-1}$ in effluent has a strong correlation with the $\mathrm{Cl}^{-1}$ in influent. It has a moderate correlation with TDS and EC in influent. $\mathrm{SO}_{4}^{-2}$ in effluent has a strong correlation with $\mathrm{SO}_{4}{ }^{-2}$ in influent but a moderate correlation with TDS, $\mathrm{EC}$, and $\mathrm{Cl}^{-1}$ in influent. EC of effluent has a strong correlation with $\mathrm{EC}$ and $\mathrm{Cl}^{-1}$ of influent and a moderate correlation with TDS of influent. TDS, TSS, and $\mathrm{PO}_{4}-\mathrm{P}$ of effluent have a moderate correlation with TDS, TSS, and $\mathrm{PO}_{4}-\mathrm{P}$ of influent, respectively.

Prediction of effluent quality based on the input variables would be very useful in ongoing operations. These relationships support measuring some parameters and calculating others using these equations. Using these equations will save the time, effort and money that can be used to conduct additional laboratory measurements. Furthermore, the efficiency gained from the use of these equations can be invested in future studies that introduce more operational parameter data, such as total nitrogen (TN), total phosphate (TP), and COD fractionation, for a longer time, using years of data for calibration and validation. Other techniques such as artificial neural networks and genetic algorithms might also be introduced.

\section{Acknowledgment}

Thanks and gratitude to the Iraqi Ministry of Municipalities and Basrah Sewerage Directorate for providing all measurements used in this study.

Table 15 Determination coefficient $\left(\mathrm{R}^{2}\right)$ among the parameters of influent and effluent wastewater

\begin{tabular}{|c|c|c|c|c|c|c|c|c|c|c|}
\hline & & \multicolumn{9}{|c|}{ Effluent Parameters } \\
\hline \multirow{10}{*}{ 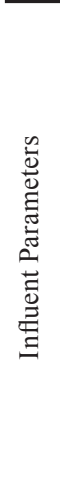 } & & COD & $\mathrm{BOD}$ & $\mathrm{SO}_{4}^{-2}$ & $\mathrm{Cl}^{-1}$ & TDS & TSS & $\mathrm{EC}$ & $\mathrm{NH}_{3}-\mathrm{N}$ & $\mathrm{PO}_{4}-\mathrm{P}$ \\
\hline & COD & 0.02 & 0.01 & 0.08 & 0.07 & 0.14 & 0.00 & 0.09 & 0.04 & 0.00 \\
\hline & BOD & 0.03 & 0.03 & 0.00 & 0.00 & 0.01 & 0.10 & 0.04 & 0.25 & 0.11 \\
\hline & $\mathrm{SO}_{4}^{-2}$ & 0.01 & 0.01 & 0.79 & 0.58 & 0.69 & 0.08 & 0.57 & 0.15 & 0.02 \\
\hline & $\mathrm{Cl}^{-1}$ & 0.01 & 0.00 & 0.46 & 0.87 & 0.54 & 0.38 & 0.61 & 0.31 & 0.03 \\
\hline & TDS & 0.04 & 0.01 & 0.64 & 0.59 & 0.70 & 0.05 & 0.68 & 0.10 & 0.01 \\
\hline & TSS & 0.01 & 0.02 & 0.27 & 0.30 & 0.26 & 0.11 & 0.17 & 0.50 & 0.02 \\
\hline & $\mathrm{EC}$ & 0.00 & 0.00 & 0.58 & 0.80 & 0.69 & 0.25 & 0.85 & 0.15 & 0.02 \\
\hline & $\mathrm{NH}_{3}-\mathrm{N}$ & 0.08 & 0.11 & 0.02 & 0.00 & 0.02 & 0.22 & 0.04 & 0.24 & 0.18 \\
\hline & $\mathrm{PO}_{4}-\mathrm{P}$ & 0.06 & 0.03 & 0.01 & 0.03 & 0.00 & 0.00 & 0.00 & 0.10 & 0.12 \\
\hline
\end{tabular}


Table 16 Linear regression equations for strong and moderate correlation among the parameters of influent and effluent wastewater

\begin{tabular}{|c|c|c|c|c|c|c|}
\hline \multirow{2}{*}{ Effluent (Y) } & \multirow{2}{*}{ Influent (X) } & \multirow{2}{*}{$\mathrm{R}$} & \multirow{2}{*}{$\mathrm{R}^{2}$} & \multirow{2}{*}{ Evaluation } & \multicolumn{2}{|c|}{ Linear Regression equation $\mathrm{Y}=\mathrm{a}+\mathrm{bX}$} \\
\hline & & & & & Intercept (a) & Slope (b) \\
\hline $\mathrm{SO}_{4}^{-2}$ & $\mathrm{SO}_{4}^{-2}$ & 0.89 & 0.79 & Strong Correlation & -58.57 & 1.00 \\
\hline $\mathrm{SO}_{4}^{-2}$ & $\mathrm{Cl}^{-1}$ & 0.76 & 0.58 & Moderate correlation & -36.50 & 0.93 \\
\hline $\mathrm{SO}_{4}^{-2}$ & TDS & 0.83 & 0.69 & Moderate correlation & -133.55 & 0.31 \\
\hline $\mathrm{SO}_{4}^{-2}$ & $\mathrm{EC}$ & 0.75 & 0.57 & Moderate correlation & -97.79 & 0.18 \\
\hline $\mathrm{Cl}^{-1}$ & $\mathrm{Cl}^{-1}$ & 0.93 & 0.87 & Strong Correlation & 112.46 & 0.78 \\
\hline $\mathrm{Cl}^{-1}$ & TDS & 0.73 & 0.54 & Moderate correlation & 158.08 & 0.19 \\
\hline $\mathrm{Cl}^{-1}$ & $\mathrm{EC}$ & 0.78 & 0.61 & Moderate correlation & 126.41 & 0.12 \\
\hline TDS & TDS & 0.84 & 0.70 & Moderate correlation & 37.88 & 0.94 \\
\hline TDS & $\mathrm{EC}$ & 0.82 & 0.68 & Moderate correlation & 23.61 & 0.58 \\
\hline TDS & $\mathrm{SO}_{4}^{-2}$ & 0.80 & 0.64 & Moderate correlation & 423.00 & 2.72 \\
\hline TDS & $\mathrm{Cl}^{-1}$ & 0.77 & 0.59 & Moderate correlation & 330.38 & 2.83 \\
\hline $\mathrm{EC}$ & $\mathrm{EC}$ & 0.92 & 0.85 & Strong Correlation & -60.21 & 1.03 \\
\hline $\mathrm{EC}$ & TDS & 0.83 & 0.69 & Moderate correlation & 306.57 & 1.48 \\
\hline $\mathrm{EC}$ & $\mathrm{SO}_{4}^{-2}$ & 0.76 & 0.58 & Moderate correlation & 999.60 & 4.11 \\
\hline $\mathrm{EC}$ & $\mathrm{Cl}-1$ & 0.89 & 0.80 & Strong Correlation & 406.10 & 5.22 \\
\hline TSS & $\mathrm{NH}_{3}-\mathrm{N}$ & -0.71 & 0.50 & Moderate correlation & 365.54 & -39.30 \\
\hline $\mathrm{PO}_{4}-\mathrm{P}$ & $\mathrm{PO}_{4}-\mathrm{P}$ & 0.81 & 0.66 & Moderate correlation & 1.20 & 1.00 \\
\hline
\end{tabular}

\section{References}

[1] Metcalf and Eddy Inc., Tchobanoglous, G., Stensel, H., Tsuchihashi, R., Burton, F. "Wastewater Engineering: Treatment, Reuse and Recovery", McGraw Hill, New York, NY, USA, 2014.

[2] Tee, P. F., Abdullah, M. O., Tan, I. A. W., Rashid, N. K. A., Amin, M. A. M., Nolasco-Hipolito, C., Bujang, K. "Review on hybrid energy systems for wastewater treatment and bio-energy production", Renewable and Sustainable Energy Reviews, 54, pp. 235-246, 2016. https://doi.org/10.1016/j.rser.2015.10.011

[3] Schwarzenbach, R. P., Egli, T., Hofstetter, T. B., von Gunten, U., Wehrli, B. "Global Water Pollution and Human Health", Annual Review of Environment and Resources, 35, pp. 109-136, 2010. https://doi.org/10.1146/annurev-environ-100809-125342

[4] Friedler, E., Pisanty, E. "Effects of design flow and treatment level on construction and operation costs of municipal wastewater treatment plants and their implications on policy making", Water Research, 40(20), pp. 3751-3758, 2006. https://doi.org/10.1016/j.watres.2006.08.015

[5] Kaindl, N., Tillman, U., Möbius, C. H. "Enhancement of Capacity and Efficiency of a Biological Waste Water Treatment Plant", Water Science and Technology, 40(11-12), pp. 231-239, 1999. https://doi.org/10.2166/wst.1999.0717

[6] Rosén, B., Morling, S. "A systematic approach to optimal upgrading of water and waste water treatment plants", Water Science and Technology, 37(9), pp. 9-16, 1998. https://doi.org/10.1016/S0273-1223(98)00265-0

[7] Sin, G., Van Hulle, S. W. H., De Pauw, D. J. W., van Griensven, A., Vanrolleghem, P. A. "A critical comparison of systematic calibration protocols for activated sludge models: A SWOT analysis", Water Research, 39(12), pp. 2459-2474, 2005. https://doi.org/10.1016/j.watres.2005.05.006
[8] Stokes, L., Takács, I., Watson, B., Watts, J. B. "Dynamic Modelling of an ASP Sewage Works - A Case Study", Water Science and Technology, 28(11-12), pp. 151-161, 1993. https://doi.org/10.2166/wst.1993.0655

[9] Westgate, P. J., Park, C. "Evaluation of Proteins and Organic Nitrogen in Wastewater Treatment Effluents", Environmental Science and Technology, 44(14), pp. 5352-5357, 2010. https://doi.org/10.1021/es100244s

[10] Oliveira, S. C., von Sperling, M. "Performance evaluation of different wastewater treatment technologies operating in a developing country", Journal of Water Sanitation and Hygiene for Development, 1(1), pp. 37-56, 2011. https://doi.org/10.2166/washdev.2011.022

[11] Harrou, F., Dairi, A., Sun, Y., Senouci, M. "Statistical monitoring of a wastewater treatment plant: A case study", Journal of Environmental Management, 223, pp. 807-814, 2018. https://doi.org/10.1016/j.jenvman.2018.06.087

[12] Qasim, A. F., Al-Obady, O. M. K. "Performance Evaluation of Al-Khadraa' Wastewater Treatment Plant, Mosul-Iraq", Tikrit Journal of Pure Science, 23(7), pp. 42-46, 2018. https://doi.org/10.25130/tjps.23.2018.109

[13] Rasheed, R. O., HamaKarim, T. A. "Impact assessment of wastewater and planning for a treatment plant within Sulaimani City, Iraq", Arabian Journal of Geosciences, 10, Article number: 507, 2017. https://doi.org/10.1007/s12517-017-3298-0

[14] Khudair, B. H., AL-Sulaimen, A. M., Jbbar, R. K. "Effluent quality assessment of Al-Diwaniyah sewage treatment plant based on wastewater quality index", International Journal of Civil Engineering and Technology, 9(10), pp. 22-31, 2018. [online] Available at: https:// iaeme.com/Home/article_id/IJCIET_09_10_003 
[15] Akkoyunlu, A., Akiner, M. E. "Pollution evaluation in streams using water quality indices: A case study from Turkey's Sapanca Lake Basin", Ecological Indicators, 18, pp. 501-511, 2012. https://doi.org/10.1016/j.ecolind.2011.12.018

[16] Libânio, M., Lopes, V. C. "Assessing the feasibility of a water treatment plant quality index", Journal of Water Supply: Research and Technology - Aqua, 58(5), pp. 354-362, 2009. https://doi.org/10.2166/aqua.2009.002

[17] Uddin, M. G., Nash, S., Olbert, A. I. "A review of water quality index models and their use for assessing surface water quality", Ecological Indicators, 122, Article number: 107218, 2021. https://doi.org/10.1016/j.ecolind.2020.107218

[18] Alexakis, D., Tsihrintzis, V. A., Tsakiris, G., Gikas, G. D. "Suitability of Water Quality Indices for Application in Lakes in the Mediterranean", Water Resources Management, 30(5), pp. 16211633, 2016. https://doi.org/10.1007/s11269-016-1240-y

[19] CCME "Canadian Water Quality Guideline for the Protection of Aquatic Life, CCME Water Quality Index User's Manual 2017 Update", [pdf] Canadian Council of Ministers of the Environment, Winnipeg, MB, Canada, 2017. Available at: https://ccme.ca/en/res/ wqimanualen.pdf

[20] Hassan, F. M., Al-Obaidy, A. H. M. J., Shaawiat, A. O. "Evaluation of Al-Shamiyah River water quality using the Canadian Council of Ministries of the Environment (CCME) water quality index and factor analysis", Desalination and Water Treatment, 116, pp. 342-348, 2018.

https://doi.org/10.5004/dwt.2018.22553

[21] Mokif, L. A. "Evaluation of Treated Water at Three Adjacent Water Treatment Stations in Al-Hilla City, Iraq by Using CCME Water Quality Index", Research Journal of Applied Sciences, Engineering and Technology, 10(11), pp. 1343-1346, 2015.

https://doi.org/10.19026/rjaset.10.1832

[22] Lumb, A., Halliwell, D., Sharma, T. "Application of CCME Water Quality Index to Monitor Water Quality: A Case Study of the Mackenzie River Basin, Canada", Environmental Monitoring and Assessment, 113(1-3), pp. 411-429, 2006. https://doi.org/10.1007/s10661-005-9092-6

[23] Haldar, D., Halder, S., Das (Saha), P., Halder, G. "Assessment of water quality of Damodar River in South Bengal region of India by Canadian Council of Ministers of Environment (CCME) Water Quality Index: a case study", Desalination and Water Treatment, 57(8), pp. 3489-3502, 2016.

https://doi.org/10.1080/19443994.2014.987168

[24] Gyamfi, C., Boakye, R., Awuah, E., Anyemedu, F. "Application of the Ccme-Wqi Model in Assessing the Water Quality of the Aboabo River, Kumasi-Ghana", Journal of Sustainable Development, 6(10), 2013.

https://doi.org/10.5539/jsd.v6n10p1

[25] Hamlat, A., Tidjani, A. E.-B., Yebdri, D., Errih, M., Guidoum, A. "Water quality analysis of reservoirs within Western Algeria catchment areas using water quality index CCME WQI", Journal of Water Supply: Research and Technology - Aqua, 63(4), pp. 311-324, 2014. https://doi.org/10.2166/aqua.2013.226
[26] de Almeida, G. S., de Oliveira, I. B. "Application of the index WQICCME with data aggregation per monitoring campaign and per section of the river: case study - Joanes River, Brazil", Environmental Monitoring and Assessment, 190(4), Article number: 195, 2018. https://doi.org/10.1007/s10661-018-6542-5

[27] Davies, J.-M. "Application and Tests of the Canadian Water Quality Index for Assessing Changes in Water Quality in Lakes and Rivers of Central North America", Lake and Reservoir Management, 22(4), pp. 308-320, 2006.

https://doi.org/10.1080/07438140609354365

[28] Ayoub, M., El-Morsy, A. "Applying the Wastewater Quality Index for Assessing the Effluent Quality of Recently Upgraded Meet Abo El-koum Wastewater Treatment Plant", Journal of Ecological Engineering, 22(2), pp. 128-133, 2021. https://doi.org/10.12911/22998993/130893

[29] Damodhar, U., Vikram Reddy, M. "Impact of pharmaceutical industry treated effluents on the water quality of river Uppanar, South east coast of India: A case study", Applied Water Science, 3(2), pp. 501-514, 2013.

https://doi.org/10.1007/s13201-013-0098-x

[30] Baghapour, M. A., Nasseri, S., Djahed, B. "Evaluation of Shiraz wastewater treatment plant effluent quality for agricultural irrigation by Canadian Water Quality Index (CWQI)", Iranian Journal of Environmental Health Science and Engineering, 10(27), Article number: 27, 2013.

https://doi.org/10.1186/1735-2746-10-27

[31] Haider, H., AlHetari, M., Ghumman, A. R., Al-Salamah, I. S., Thabit, H., Shafiquzzaman, M. "Continuous Performance Improvement Framework for Sustainable Wastewater Treatment Facilities in Arid Regions: Case of Wadi Rumah in Qassim, Saudi Arabia", International Journal of Environmental Research and Public Health, 18(13), Article number: 6857, 2021.

https://doi.org/10.3390/ijerph18136857

[32] Ebrahimi, M., Gerber, E. L., Rockaway, T. D. "Temporal performance assessment of wastewater treatment plants by using multivariate statistical analysis", Journal of Environmental Management, 193, pp. 234-246, 2017.

https://doi.org/10.1016/j.jenvman.2017.02.027

[33] Ibrahim, M. N. "Effluent Quality Assessment of Selected Wastewater Treatment Plant in Jordan for Irrigation Purposes: Water Quality Index Approach", Journal of Ecological Engineering, 20(10), pp. 206-216, 2019

https://doi.org/10.12911/22998993/112491

[34] Jamshidzadeh, Z., Tavangari Barzi, M. "Wastewater quality index (WWQI) as an assessment tool of treated wastewater quality for agriculture: a case of North Wastewater Treatment Plant effluent of Isfahan", Environmental Science and Pollution Research, 27(7), pp. 7366-7378, 2020.

https://doi.org/10.1007/s11356-019-07090-x

[35] Wahang Saran Company "Environmental Impact Report for the construction of a Wastewater Treatment Plant in Al Thagher Subdistrict. Brsrah-Iraq", Wahang Saran Company, Tehran, Iran, Rep. 1, 2016. 
[36] Rice, E. W., Baird, R. B., Eaton, A. D. (eds.) "Standard Methods for the Examination of Water and Wastewater", American Public Health Association, Washington, DC, USA, 1999.

[37] Cossu, R., Fantinato, G., Pivato, A., Sandon, A. "Further steps in the standardization of BOD5/COD ratio as a biological stability index for MSW", Waste Management, 68, pp. 16-23, 2017.

https://doi.org/10.1016/j.wasman.2017.06.035
[38] Al-Shammari, A. M. "Environmental pollutions associated to conflicts in Iraq and related health problems", Reviews on Environmental Health, 31(2), pp. 245-250, 2016.

https://doi.org/10.1515/reveh-2015-0024

[39] Kumar, A., Dhall, P., Kumar, R. "Redefining BOD:COD ratio of pulp mill industrial wastewaters in BOD analysis by formulating a specific microbial seed", International Biodeterioration and Biodegradation, 64(3), pp. 197-202, 2010.

https://doi.org/10.1016/j.ibiod.2010.01.005 